\title{
SOBRE AS DIFERENÇAS ENTRE ÉTHOS COM EPSÍLON E ÊTHOS COM ETA
}

Miguel SPINELLI $I^{1}$

- RESUMO: O objetivo deste artigo consiste em detalhar como os termos éthos (grafado com epsílon) e êthos (com eta), ao mesmo tempo em que diferem, se completam entre si. Visto que os dois termos estão intimamente associados aos conceitos de phýsis (de natureza) e de moîra (de necessidade ou destino) este estudo quer também explicitar como se dá essa inter-relação.

- PALAVRAS-CHAVE: éthos, êthos, phýsis, moîra.

\section{De Homero a Aristóteles}

A diferenciação entre éthos e êthos se deu bem cedo no contexto da cultura grega. O êthos, grafado com eta, remonta a Homero, e o éthos, com epsílon, a Ésquilo, o fundador da tragédia grega. O êthos, na grafia de Homero, remonta ao século VII a.C., e comparece com uma significação um tanto abstrata, na medida em que designa os usos e os costumes enquanto relativos a modos (genéricos) de viver, ou seja, a uma sabedoria. Éthos, em Ésquilo (525456 a.C.), designa mais ou menos a mesma coisa, mas, fundamentalmente, a tradição, no sentido de o que é habitual, corriqueiro, usual, etc., e que vem a se impor como uma sabedoria. Éthos, assim como êthos, a partir do que observaram os filólogos, "deriva da raiz sfeth" (Esser, 1976, p.899), ${ }^{2}$ da qual, como veremos, adveio o vocábulo latino suetus e também o nosso consueto.

1 Professor de História da Filosofia Antiga do Departamento de Filosofia da Universidade Federal de Santa Maria, Rio Grande do Sul. Artigo recebido em 10/2008 e aprovado em 08/2009.

2 "... éthos (tramandato fin da Eschilo) deriva dalla radice sfeth, donde per es. il latino suetus e anche il nostro consueto, e indica fondamentalmente la tradicione, l'abitudine, la consuetudine, il costume, l'usanza ecc. (...); il vocabolo affine êthos (fin da Omero) ha un'accentuazione più astratta: costume, uso, maniera di vivere". 
O primeiro a reconhecer essa variação foi Aristóteles (384-322 a.C.), na Ética a Nicômaco. Ele apenas a mencionou, sem, todavia, atribuir qualquer valor semântico (relativo à significação), a não ser meramente gráfico (como maneira de escrever ou de representar os mesmos conceitos sob grafias diferentes). A "palavra ética (disse ele), êthikê, decorreu de uma pequena variação (mikròn parekklînon) de éthous"; nesse mesmo contexto, ele disse também que "a virtude, a aretê proveio de êthikê ex éthous" (II, 1, 1103a 1718, Cf. Aristóteles, 1984)", ${ }^{3}$ ou seja, que a aretê foi gerada dos usos e dos costumes. Na medida, pois, em que ele tomou a aretê como sujeito de seu dizer, com tais termos êthos e éthos, sem distinção, ressaltou uma sabedoria ancestral, edificada no tempo, transmissora de qualidades relativas ao viver e ao fazer bem feito Quando o sujeito recai sobre a ética (ao dizer que "êthikê decorreu de éthous") fica explícito que ele próprio optou (o que em sua época já era corriqueiro) pela grafia do êthos com eta ao invés do éthos com epsílon.

Quando na Metafísica, pelo menos em dois momentos, ${ }^{4}$ Aristóteles se reporta à sua Ética, ele se vale de êthos com eta e não com epsílon. O mesmo se dá na Política. ${ }^{5}$ Na Metafísica, quando (também em dois momentos) ele se vale do termo éthos com epsílon, dele lança mão como contraposto entre o que se faz (ou é feito) por natureza (digamos, mediante impulsão natural - phýsei tivì poieîn) ao que é feito mediante éthos. Ao fazer natural (phýsei tivì poieîn), restrito ao que ele chama de "seres inanimados (ápsycha), ele contrapõe o fazer ético dos artesãos (dos cheirotéchnas), dando a entender que é ao fazer manual, a aquele que se faz com as mãos, ou seja, não diretamente derivado da razão (antes das mãos), que ele aplica o conceito de éthos com epsílon. ${ }^{6}$ E, efetivamente, num outro passo da Metafísica, ele outra vez se vale do mesmo éthos com epsílon, a fim de expressar um fazer que depende do que ele denomina de tà éthe. ${ }^{7}$ termo que Guilherme de Moerbek, em sua tradução latina, verteu para consuetudines (no sentido de o que é costumeiro, habituado, familiarizado). Logo na sequência, justo para explicar o que estava querendo dizer, Aristóteles, ao invés de éthos, se

3 Proveio foi traduzido de perigínetai.

4 "Dissemos na Ética (en toîs êthikoîs) qual a diferença entre arte, ciência e outros conhecimentos do mesmo gênero" (ARISTÓTELES. Metafísica. I, 1, 981b 25-26); "... tà êthiká..." (ARISTÓTELES. Metafísica. I, 6, 987a 1); Idem, v. 29, 1025a 12.

5 "... como na Ética foi dito anteriormente - en toîs êthikoîs eírêtai próteron" (ARISTÓTELES. Política. II, 1, 1261a 30-35); "... eírêtai próteron en toîs êthikoîs - como foi dito anteriormente na Ética" (ARISTÓTELES. Politica. III, 5, 1280a 15-20); “... perì tôn hêthikôn” (ARISTÓTELES. Política. III, 5, 1282b 20-30).

6 ARISTÓTELES. Metafísica. I, 1, 981b 4-5; Idem IX, 5, 1047b 31-32.

7 ARISTÓTELES. Metafísica. II, 3, 994b 32. 
vale então de sýnêthes, termo que designa justamente o que se está acostumado, habituado: aquilo que, por ser próprio de um indivíduo ou de um grupo, por estar acostumado, "se deixa entender" melhor, e, em razão disso, produz bons efeitos. $^{8}$

Pelo que está posto na Metafísica, não dá, com efeito, para dizer que Aristóteles restringe o éthos com epsílon aos usos ou costumes familiares, ou então a toda habilidade adquirida (adestrada) no exercício cotidiano do fazer, deixando para o êthos com eta a expressão de toda a capacitação ou habilidade derivada da razão. Quer dizer: não dá para logo supor aqui, por exemplo, que, dos dois modos amplos de aprendizado (um, digamos, da razão que aprende com as mãos, e, outro, o das mãos que seguem os comandos da razão - ou, dito outro modo, que o aprendizado derivado do fazer mediante a experiência que instrui a razão e o fazer derivado da razão que instrui e antecipa a experiência), o primeiro corresponderia ao éthos, e, o segundo, ao êthos. Ocorre que também para o termo êthos Aristóteles atribui ambas significações, qual seja, o da capacitação ou habilidade do fazer mediante experiência e o da habilidade ou capacitação ${ }^{9}$ germinada pela reflexão filosófica (dianoética ${ }^{10}$ ). O que, além disso, se pode com igual certeza dizer, é que ele opta pelo termo êthos com eta (ao invés do éthos com épsílon), a fim de dar nome ou expressão a toda a sua tratativa ética, mais exatamente, quando, em seus tratados éticos, quer conceituar filosoficamente a aretê (outro termo de difícil compreensão) por um ponto de vista dianoético.

De Homero a Ésquilo, e, por fim, a Aristóteles, há, pois, um longo caminho, em que o êthos e o éthos, independentemente da grafia, incorporam vários significados. A exemplo de Homero, também Sófocles (496-405 a.C.), grafou o êthos com eta, a fim de expressar tanto um modo de ser (nos termos de o que é) quanto uma natureza específica. Em ambos os casos, nele o êthos designa igualmente uma condição ou um conjunto de características em dependência do qual se desprende um modo de portar-se quer dado por natureza (ou espontaneamente, sem empenho ou sem esforço), quer derivado da noese, de um empenho organizado do dizer e pensar. O que, por exemplo, Sófocles, no Ajax, põe como fala de Tecmessa (da escrava e aman-

8 tò gàr sýnêthes gnôrimon (ARISTÓTELES. Metafísica. II, 3, 995a 3).

9 Platão, no Menôn (70b), se valeu justo do termo tò éthos com epsílon, a fim de expressar uma capacitação.

10 Efetivamente Aristóteles distingue dois tipos de virtudes: as que denomina de dianóeticas ou intelectuais e as morais - mèn dianoêtikàs tàs dè êthikás (Ética a Nicômaco. I, 12, 1103a 5). Mas, o que aqui está em destaque não é propriamente esta distinção (feita por ele no interior da própria Ética), e, sim, a afirmação de que reserva o termo êthica para a aretê filosoficamente concebida, esta que, segundo ele, se divide em aretê dianoêtikàs tàs dè êthikás, ou seja, em virtudes intelectuais e virtudes morais. 
te de Ajax) é por si só bastante ilustrativo: "Por Deus (suplica Tecmessa a Ajax), te deixe cativar"; ao que Ajax responde: "Estás louca! Tenho o meu modo de pensar, e queres agora me domesticar com outro êthos" (Ajax, vv 593-595. cf. Sófocles, 1958). ${ }^{11}$ Sófocles, nesse passo, faz referência a um êthos noético, a um modo de pensar, mais exatamente, a um domínio (organizado em termos de pensamento e discurso) em dependência do qual um indivíduo vem a ser capaz de reger a sua vida sem se sujeitar a qualquer outro governo (dos humanos ou dos deuses) que não o seu. Ainda nesse contexto, perante a insistência de Tecmessa (que todo momento e por qualquer motivo propunha que Ajax recorresse ao beneplácito dos deuses), irritado, Ajax responde: "Tu me aborreces com os deuses. Não sabes que não lhes devo mais nada?". Espantada, Tecmessa se indigna: "Não blasfeme nesse tom, oh! meu senhor. Eu me estremeço"; ao que Ajax retruca: "não vou me deixar cooptar, ser governado pelos deuses feito uma criança" (Ájax. vv. 589-595; cf. Sófocles, 1958).

Na Antígona, na fala de Sófocles posta na boca de Creonte, consta de modo claro o sentido de êthos enquanto natureza (como um modo de ser dado sem esforço). Creonte se dirige a Hemão, seu filhoemão, seu filhoHe: "Oh! vil natureza que se impõe a uma alma feminina - Ô miaròn êthos kaì gynaikòs hýsteron" (Antígona. v. 746; cf. Sófocles, 1958). Por referir-se a Hemão, êthos, aqui, não indica, diretamente, as qualidades da alma de uma mulher, e, sim, de uma alma feminina, no caso, dotada de qualidades que definem a alma da mulher. A exclamação - ô miaròn êthos - relativa ao modo de ser da mulher em geral, é dirigida a Hemão em razão de ele se deixar possuir por um excessivo sentimento de piedade (de compaixão e de comiseração), que o leva a clamar bom senso ao pai, no sentido de que poupe a vida de Antígona, da qual é noivo. ${ }^{12}$

O casamento de Édipo com Jocasta, incestuoso, impusera o caos na gênese, ou seja, fez introduzir o abismo na ordem habitual das coisas. Ora, perante um destino inusitado, Creonte não queria ver seu filho (Hemão), tampouco seus netos, participando de uma sina repudiada pelos humanos e pelos deuses. Creonte, ademais, via na súplica do filho mais paixão que razão: o contra-senso sobrepondo-se ao bom senso. Ele observava na atitude de Hemão um modo feminino de portar-se, uma gýnaikías. Daí que é nessa atitude (suposta como um modo de portar-se em consequência de um

11 "TEK. Pròs theôn, malássou. AI. Môrá moi doxeîs phroneîn ei toumòn êthos árti paideúein noêis".

12 Cabe lembrar que Antígona era filha de Édipo com Jocasta, irmã de Creonte. Jocasta era mãe de Édipo, de modo que Antígona era ao mesmo tempo filha e irmã de Édipo... Creonte não queria ver seu filho casado com alguém fruto de um casamento incestuoso. Ele receava que seu filho (Hemão) e possíveis netos viriam a participar do mesmo abominável destino (repudiado pelos humanos e pelos deuses) dentro do qual participaram Jocasta, Édipo e Antígona. 
modo de ser e de pensar) que Sófocles condensa o êthos, por ele referido sob dois termos: como miaron e como hýsteron... O êthos de Hemão é miaron porque manifesta um modo de portar-se que não condiz exatamente com o que se espera de um homem, de uma alma viril; é miaron porque comporta um conjunto de qualidades (impregnadas como se fossem nódoas na alma) que impõem uma especificidade (uma índole) à mercê da qual, aquele que a detém por ela se deixa levar ou se conduzir. Hýsteron é a expressão dessa especificidade, ou seja, de algo (de certo modo indefinido e inabordável, e, do mesmo modo oculto) que está por detrás do que é manifesto. Daí que hýsteron (na medida em que aqui define o êthos ou a natureza feminina) expressa um algo que é detentor de uma ancestralidade, que, todavia, está presente, e que, em relação a ele, pouco ou nada é possível de ser feito, a não ser deixar-se levar por ele. Além disso, hýsteron designa também, e de modo muito significativo, um algo que vem depois, como se o antes e o agora se conjugassem numa continuidade póstuma... Enfim, com apenas dois termos - miaron e hýsteron -, Sófocles expressa mui claramente o que o êthos, suposto como natureza de algo, significa.

Não só nos poetas da tragédia, como também nos antigos poetas-filósofos (em Heráclito e em Parmênides) encontramos a variação entre êthos e éthos. Parmênides recorreu ao éthos no frag. 7, verso 3, trecho em que pede aos seus discípulos que se afastem do que denominou de "éthos polýpeiron - éthos de muita empiria" - termo com o qual ele definiu a dóxa, mais precisamente o que classificou de broton dóxas, ou seja, de as opiniões dos mortais (DK 28 B 1,30; cf. Diels \& Kranz, 1989). Simplício (um neoplatônico do VI século, fecundo comentador de Aristóteles) explicitou assim o que Parmênides concebeu por dóxa: como um saber "popular e enganador, mas não absolutamente falso", apenas dotado de muitos enganos, carente de rigor lógico, de acabamento ou de completude (DK 28 A 34; cf. Diels \& Kranz, 1989).

É clássica a "contraposição" suposta por Parmênides entre dóxa e aléthês, dois termos que, todavia, expressam uma mesma questão: o universo da empiria, ou, mais exatamente, o universo do que é ser em sua realidade própria, numa palavra, a questão da verdade (da alétheia). A alétheia, do ponto de vista de Parmênides (questão que, explicitamente, comparece em Platão, na "Alegoria da Caverna"13), tem graus ou níveis, e pode ser considerada de duas amplas maneiras: uma, como dóxa; outra, como epistême. A dóxa é o contraposto da alêthês epistêmica e expressa o universo das verdades fracas (efêmeras, transitórias); a epistême congrega o universo das verdades fortes (resistentes, duradouras). Ela diz respeito a um saber come-

13 República, livro VII. 
dido, recolhido com prudência, com circunspecção noética, um saber que, vinculado a uma métrica, a uma nóêsis ou racionalidade equitativa, é, por fim, dado como veraz.

Parmênides concebeu a alétheia sob dois sentidos amplos: um forte e um fraco. Em sentido forte, a alétheia é o saber que circunscreve, num mesmo logos, o ser, o dizer e pensar, e que, por força dessa circunscrição, promove [o que Parmênides chamou de] a "alêtheiês eukykléos, a verdade bem redonda" (DK 28 B l, 29; cf. Diels \& Kranz, 1989). É por ser eukykléos que a alêthês (o que se manifesta como coisa real) vem a ser epistêmica. É epistêmica porque (em dependência da circunspecção e métrica noética) resulta num saber dotado de uma pístis qualificada, persuasiva (peithós), tão convincente e acabada ("arredondada") que desperta a confiança, a ponto de atrair para si uma obediência (uma peíthomai) espontânea. Em seu sentido fraco a alêtheia coincide com a própria dóxa. Ela diz respeito, primeiro, à verdade do aparecer, que, enquanto tal, não se pode negar - quer dizer: não podemos negar que as coisas, de alguma maneira, se mostram para nós, ou que, nós, de alguma maneira, estabelecemos vínculos com as coisas que se põem em nosso caminho; segundo, à verdade forjada em decorrência desse aparecer - verdade, aqui, no sentido de uma persuasão ou confiança, e não no sentido de uma investigação epistêmica do é ser da coisa real.

A dóxa é uma alêtheia fraca porque forja o ser restringindo-se à aparência, com o que promove uma convicção desvinculada do dizer noético, sendo apenas um dizer retórico. Ela não só tem como fundamento o aparecer fenomênico (o que é dado ao sensível, manifesto externamente ao senso comum) como também o consuetudinário: os usos e costumes forjados pela força do hábito. Parmênides define a dóxa numa única expressão: ouk éni pístis alêthês, ou seja, como um saber em que nele próprio não há (não é dotado de uma) confiança verdadeira (DK 28 B 1,30; cf. Diels \& Kranz, 1989). $\mathrm{O}$ crédito (o pressuposto de certeza que gera a persuasão) não deriva dele mesmo, mas vem de fora; a alêthês não lhe é inerente, mas forjada por indivíduos (pelos mantikós, por exemplo) que dotavam, sem métrica e sem apelo à nóesis, as manifestações fenomênicas de sentido e verdade. ${ }^{14}$ Aos que punham fé e que se apropriavam desse tipo de saber, Parmênides os denomina de "multidão indecisa - ákrita phyla" (DK 28 B 6,7; cf. Diels \& Kranz,

14 Os mânticos ganhavam a vida interpretando oráculos e dando sentido aos sinais. Para cada fenômeno, por exemplo, para um trovão, para um raio ou relâmpago, até para uma revoada de pássaros, para o sibilo dos ventos, eles atribuíam intenções "divinas" ou significados "divinos", sem, com efeito, perguntar pelo fenômeno em si ou por sua realidade própria. Eles, e os cultores do mito jamais se preocupavam pelo o que é ser do aparecer, por suas causas ou razões ou pela nóesis que lhe dá ser. Os fenômenos eram apenas tratados como um mero aparecer, frente ao qual, seitas de intérpretes e de adivinhos se precipitavam em forjar e impor um conteúdo. 
1989): de turba que se deixa governar por "olhos sem visão", por "ouvidos sem audição" e por "língua ruidosa" (DK 28 B 7,4-5; cf. Diels \& Kranz, 1989).

Aqui, sob esses termos (qual seja, o deixar-se "governar pelo olho sem visão, pelo ouvido ressoante e pela língua ruidosa"15), Parmênides não só se reporta ao indivíduo em particular (ao indivíduo que vê e ouve sem qualquer preocupação noética) como também à seita dos mânticos (dos adivinhos e intérpretes) que se precipitavam em forjar explicações a todo e qualquer sinal, inclusive, dar ser ao que não tem ser. Por um lado, diante de fenômenos reais que se mostram, tais intérpretes (destituídos de métrica e de circunspecção noética), não tinham qualquer compromisso com a verdade, e sequer levavam em conta o aparecer fenomênico em sua especificidade própria (condizente com o é ser de alguma coisa manifesta); por outro, diante do não-ser (do que não existe), do que não se deixa ver e nem ser ouvido, impunham (valendo-se de um logos meramente retórico) um conteúdo como se lhe dessem ser. E, além de impor tal conteúdo, ruidosamente o divulgavam, como se fosse a verdade do que as coisas, em sua realidade própria, são...

Eis, enfim, o contexto (inerente ao qual prevalece uma persuasão ou convencimento artificial, forjado) em referência ao qual Parmênides concebeu o éthos polýpeiron, por ele logo definido de broton dóxas. Ele é polýpeiron, porque põe demasiado crédito na empiria; porque o seu cultivo não vai além do mero aparecer fenomênico. Antes de um saber, em sentido forte, ele é expressão de uma pístis: de uma fé pública forjada como verdade, revertida em opinião usual, corriqueira, e, bem por isso, em dóxa (em um saber sem compromisso com o ser). Bem por isso é broton dóxas, primeiro, porque dele a maioria dos homens deriva o seu "saber", no qual deposita total confiança, a ponto de tomá-lo por baliza e orientação do viver e agir; segundo, porque é efetivamente brótos, ou seja, um saber "mortal", passageiro, que se esvai como a vida dos indivíduos ou das gerações. Broton, aliás, (ou seja, o qualificativo de mortal) não se aplica tão-somente aos homens, mas, sobretudo, ao universo das opiniões: um modo de conceber sobre o qual a maioria assenta o pensar e o dizer (sem compromisso com o ser). As opiniões são mortais na medida em que forjadas sem qualquer preocupação apurada de saber, sem o cuidado de combinar o ser (a realidade perceptível do que as coisas são) com o humano pensar e dizer: um do outro inseparáveis. Se, separados, o pensar, sem o dizer (sem o universo simbólico do discurso), não se exercita, e, o dizer, se desamparado do pensar, resta carente de verdade.

15 Essa tradução é preferível às anteriores. Idem DK 28 B 7, 4-5. 


\section{Heráclito e Sófocles: o êthos vinculado a gnômas, a daímôn e a moîra}

O êthos, grafado com eta, comparece em dois fragmentos de Heráclito: no de número 78: "O êthos humano não tem conhecimentos, mas o divino tem" (DK 22 B 78; cf. Diels \& Kranz, 1989); e no 119: "o êthos do homem é o seu daímôn" (DK 22 B 119; cf. Diels \& Kranz, 1989). São dois fragmentos bastante lacônicos, complexos, mas com algumas indicações do que vem a ser o êthos a que Heráclito se refere. Pelo que está dito no fragmento 78, tanto o humano (anthrôpeion) quanto o divino (theîon) são dotados de êthos, mas com uma diferença: o êthos divino tem a posse de conhecimentos (gnômas); o humano não a tem. Já pelo que consta no fragmento 119, nele há uma definição explícita do que vem a ser o êthos: ele é o daímôn humano. Assim como no fragmento 78 o êthos é concebido por Heráclito relacionado à gnômas (à potência e à posse de conhecimentos), no 119 ele o concebe vinculado ao daímôn, sem que, de imediato, saibamos exatamente o que significa. Por isso a necessidade de investigá-los sob esses dois aspectos: o êthos vinculado à gnômas e o êthos vinculado a daímôn. Porém, em decorrência desses dois, se imporá um terceiro: o êthos vinculado à moîra (ao destino).

A) O êthos vinculado a gnômas: Existem, na tradição, três breves comentários que foram certamente dirigidos ao frag.78: a) de Calcídio (estoico latino do V século, tradutor e comentador de Platão): "Heráclito (...) estabeleceu uma conexão entre a nossa razão e a razão divina que rege e governa as coisas do mundo: devido a essa união inseparável, o homem consegue conhecer os decretos da razão excelsa..." (DK 22 A 20; cf. Diels \& Kranz, 1989) ${ }^{16}$; b) de Sexto Empírico (do II século d.C., médico e adepto do ceticismo): "Heráclito declarou explicitamente que o homem não é racional, pois somente é dotado de inteligência o invólucro celeste" (DK 22 A 16; cf. Diels \& Kranz, 1989); c) de Apolônio (pitagórico do I século d.C., originário da cidade turca de Tiana): "Heráclito, o filósofo da Natureza, dizia que, por natureza, o homem é desprovido de razão" (DK 22 A 16; cf. Diels \& Kranz, 1989).

16 O conjunto da citação: "Heráclito, com o qual concordam os estoicos, liga nossa razão com a razão divina, regente e moderadora das coisas do mundo: devido a essa união inseparável, chega a conhecer os decretos da razão divina e, enquanto as almas dormem, anuncia-lhes, com a ajuda dos sentidos, o futuro. Disso surgem imagens de lugares desconhecidos, e figuras de homens, tanto vivos como mortos - Heraclitus vero consentientibus Stoicis rationem nostram cum divina ratione conectit regente ac moderante mundana: propter inseparabilem comitatum consciam decreti rationabilis factam quiescentibus animis ope sensuum futura denunciare. Ex quo fieri, ut adpareant imagines ignotorum locorum simulacraque hominum tam viventium quam mortuorum" (Calcídio. Comentário sobre o Timeu de Platão, 251, ed. Wrobel, p. 384, 10). 
Tanto o comentário de Calcídio quanto o de Sexto Empírico reproduzem, sob o conceito de divino (theîon), a mesma ideia dos pitagóricos de que há inerente ao Cosmos uma "razão ou inteligência que tudo governa"; Sexto Empírico, no entanto, acrescenta que "o homem (por natureza) não é racional" -, comentário com o qual ele reproduz a mesma observação de Apolônio de Tiana: "por natureza, o homem é desprovido de razão". A questão que põem em foco é a seguinte: o homem é desprovido de razão porque só "o invólucro celeste", ou seja, o divino é dotado de inteligência (detém gnômas). Daí, primeiro, que, divino, theîon, não diz respeito a um Deus, mas ao Kósmos, que, em si mesmo, está envolvido por uma "sabedoria" interna da qual deriva o seu modo natural de ser e de agir. No Kósmos, ser, saber e agir coincidem, de modo que em seu orbe tudo se faz ou dá (isso de modo constante e cumulativo) por força dessa coincidência; por isso detém gnômas: porque ele, e tudo o que nele se realiza (nos termos da phýsis) vem a ser conforme o que deve ser segundo os ditames da sabedoria ou natureza que lhe é inerente, sem qualquer necessidade de valer-se ou receber algo de fora, e sem desvios, ou seja, segundo as determinações próprias que se dão no ciclo do tempo.

Relativos a nós humanos (afora o que diz respeito às determinações próprias de nossa natureza física), em nós não há coincidência entre ser, saber e agir. Não somos, por natureza (e aí está o que diz Heráclito), providos de razão: de determinações que façam espontaneamente; ou que, sem esforço, levam a concordar em nós o ser, o saber e o agir. Xenófanes (mestre de Heráclito e também de Parmênides) foi o primeiro filósofo a formular esse pressuposto. Ele disse o seguinte: "Os deuses não revelaram desde os primórdios todas as coisas aos mortais; foi com o tempo, que, procurando, os homens encontraram o melhor" (DK 21 B 18; cf. Diels \& Kranz, 1989). ${ }^{17}$ Sófocles, algum tempo depois (496-406 a.C.), disse algo semelhante: "Quando os deuses deram aos homens a razão <phrénas >, eles os dotaram do mais precioso de todos os bens" (Antígona. vv. 183-184; cf. Sófocles, 1958). Quanto a Heráclito, no fragmento 116, ele dissera o seguinte: "A todos os homens é facultado o conhecer a si mesmos e o pensar sensato" (DK 22 B 116; cf. Diels \& Kranz, 1989). ${ }^{18}$ Foi como se dissesse: nós homens fomos "dotados apenas da potência do saber", do qual, por natureza, não temos a posse. Noutros termos: por natureza não estamos dotados de conhecimentos, mas apenas da potência ou capacidade de conhecer. Daí que (conforme o frag-

17 "Encontrar sem pesquisa (disse o pitagórico Arquitas de Taranto) é difícil e raro (...); e aquele que nada entende da investigação nada pode encontrar" (Estobeu. Florilégio. IV, 1, 139 ed. Hense; DK 47 B 3).

18 anthrôpoisi pâsi métesti ginôskein heôntoùs kaì sôfroneîn (Estobeu. Florilégio, III, v. 6). 
mento 78), não somos, por natureza, nem propriamente racionais e nem rigorosamente humanos. Para sermos de fato humanos carecemos do exercício da faculdade de pensar, em dependência da qual edificamos o nosso ser e o nosso agir, e também nos ciframos: damo-nos a conhecer a nós mesmos para nós mesmos -, tarefa que, desde cedo, fez prosperar a Filosofia.

Do fato de ao homem não ser dada a plenitude da razão divina (de modo semelhante como não lhe é dada a imortalidade), não se segue que haja entre deuses e homens uma relação de inferioridade -, tanto mais que o divino não designa um ser, mas um acontecer. Diz Heráclito: "O homem é como uma criança diante do divino (pròs daímonos), tal como uma criança diante do homem" (DK 22 B 79; cf. Diels \& Kranz, 1989); ${ }^{19}$ "O mais sábio dos homens (dizia também Heráclito), perante o divino (pròs theón), é semelhante a um símio, em sabedoria, beleza e tudo o resto". ${ }^{20}$ Divino (aqui por Heráclito expresso sob dois termos gregos correlativos: daimónion e theón) diz respeito ao que, no contexto da condição humana, é superlativo: denota um elevado grau de certa qualidade, que se impõe ao homem como referencial e aspiração. Daí que, referido ao divino, o homem (e, por consequência, o seu êthos) é o ser (ou êthos) da cisão: a expressão maior de certo conflito. Ocorre que, por natureza, somos dotados de inteligência, mas disso não se segue que, também por natureza, somos possuidores de ciência, ou que, por ela, nos tenha sido dada a destinação do viver humano. Cindido, cabe a nós humanos o esforço personificador do êthos de nosso próprio viver, e, portanto, a edificação de um modo próprio de destinação de nossa vida (em consonância com a nossa própria condição - termo que se põe ao de inferioridade).

B) O êthos vinculado a daímôn: Daímôn é tomado como expressão de uma força ou de um poder (de um animus, conforme expressaram os latinos) em sentido ativo, e não como se fosse um ente em sentido passivo. Assim como, a rigor, theîon não se refere a um Deus, daímôn não diz respeito a um Demônio: a um ente soberano detentor em si mesmo de toda a malícia e maldade. Daímôn, por vezes, designa apenas o destino, a própria sorte. ${ }^{21}$ um apelativo comum ao que acontece de bom ou de ruim na vida dos indivíduos; outras vezes é apenas expressão de um animus, que, atribuído ao êthos humano, faz referência, digamos ${ }^{22}$ a uma potência intermédia, nem pura determinação da phýsis, nem puro arbítrio. Daí que, êthos, vinculado a daímôn, indica a própria condição humana: um vigor interno em depen-

19 anêr nêpios êkouse pròs daímonos hóokôsper paîs pròs andrós (Orígenes. Contra Celso, VI, 12).

20 anthôpôn ho sophôpatos pròs theòn píthêkos phaneîtai kaì sophíai kaì toîs állois pâsin (Platão. Hípias maior, 289b; DK 22 B 83).

21 Cf., por exemplo, ÉSQUILO. Os Persas, vv. 921-941.

22 Em conformidade com o frag.78: "O êthos humano não tem conhecimentos...". 
dência do qual o humano edifica e gerencia o seu modo próprio de ser e de agir. É, pois, em vista dessa edificação, que êthos é o daímôn humano: ele é o daímôn porque expressa um saber acumulado na alma, feito um depósito do qual colhemos a experiência vivida fecundada pela phrónêsis (pelo exercício do pensar).

Daímôn, ademais, não diz respeito diretamente a um gênio ou espírito do bem ou do mal que preside por dentro, como se fosse de fora, ${ }^{23}$ a destinação humana. Daímôn, então, na medida em que está vinculado ao destino humano, é expressão de um inabordável tomado como explicação primeira de um acontecer (para o bem ou para o mal): "A causa primeira de todo infortúnio (escreveu Ésquilo), é um daímon, tão luminoso quanto malvado, que se esconde por aí <phaneìs hê kakòs daímôn pothén>" (Os Persas, vv. 353-354; cf. Ésquilo, 1964). Daí que daímôn (num sentido estritamente ético-filosófico) é acima de tudo expressão de um arbítrio interno, de uma espécie de consciência (natural unívoca, residente em cada um) da qual os humanos se valem para o bem ou para o mal. Enquanto disposição (héxis) interna é expressão de uma potência comum a todos, que, em cada um (oikôumen), se dá feito um estímulo (força ou vigor) do qual todos têm a posse. Não se trata, como já dito, de uma força in concreto, que age ao seu próprio acaso, ou em dissonância com o arbítrio do indivíduo humano que a detém. Claro que de algum modo ela é dissonante. Mas, mesmo assim, à mercê do arbítrio... Ela é dissonante em razão do descompasso entre o querer (o desejado pela intenção) e o agir (o realizado pela ação). O certo é que ninguém, por mais que se empenhe, consegue plenamente realizar o vigor que, dentro da alma, recolhe o estímulo.

Ethos e daímôn (pelo que consta no fragmento 119: "o êthos do homem é o seu daímôn") são correlativos: um implica de tal modo o outro que se equivalem. Em geral, traduzido por índole (caráter, natureza), o termo daímôn alude a um modo humano de ser, sob dois aspectos: um, ao modo de como o homem, por natureza, habita a si mesmo; outro, de como o homem, valendo-se da natureza que lhe é própria, é capaz de por si mesmo reger e edificar a sua própria destinação humana. Nessa vinculação entre êthos e daímôn, o termo êthos insinua justamente o modo humano de habitar a si mesmo, ${ }^{24}$

23 Robert Pignarre traduziu assim os versos 136-137 dos quais sobretudo nos servimos. Pignarre seguiu uma interpretação clássica, que, estamos certos, não mais se sustenta: "Le génie commun qui preside à notre sort nous oblige à flatter les autres pour vivre". Pignarre deu a daímôn um significação que o contexto poema de Sófocles não comporta; com efeito, ao acrescentar o conceito de "commun" (que não consta no original) foi muito feliz, visto que o contexto da significação comporta. Os termos "preside" e "oblige" são coerentes.

24 "L'interpretatione della parola êthos nel senso di indole, carattere, natura personale, maniera d'essere, non par dubia in B 119. (...) l'opposizione fra l'êthos umano, al quale sono negati i pensieri 
e, o daímôn, de destinar a si mesmo. Na medida, pois, em que o êthos insinua a morada, o daímôn (tendo em vista o fazer-se humano em decorrência das propensões de sua natureza) designa o seu destino, ou seja, a direção (o para onde leva o querer e o agir) que a todo homem cabe zelar e prover. Referido ao frag. 78 ("O êthos humano não tem conhecimentos"), o termo êthos agrega, neste contexto, um sentido essencialmente epistêmico; não se trata, aqui, da expressão de um mero acúmulo de dotes ancestrais, ou de um conjunto de bens derivados do saber ou da cultura, mas, sim, de uma disposição interior (natural), mediante a qual o humano se potencializa em vista do fazer bem feito ou do que é devido.

Há um fragmento de Demócrito que nos ajuda a esclarecer a inter-relação entre êthos e daímôn. A psychê é a morada do divino, disse ele: psychê oikêtêrion daímonos (DK 68 B 171; cf. Diels \& Kranz, 1989). Sob esses termos, ele quis dizer que, do daímon, a psychê é a oikía (do divino a alma é a morada); e que, em contrapartida, da psychê, o daímôn é o oikêtês (da alma o divino é o habitante). Portanto, entre psychê e daímon, Demócrito estabeleceu uma profunda dependência e uma explícita familiaridade. Enquanto hospedeiro da alma o daímôn seria o constitutivo de sua interioridade, de modo que, se queremos nos deter com ele (ou seja, com o que é divino em nós), é no interior da psychê, dentro e não fora dela, que podemos ou estamos em condições de encontrá-lo. Heráclito disse algo semelhante: "Da alma é o logos - psychês ésti lógos..." (DK 22 A 17; cf. Diels \& Kranz, 1989), como se dissesse que o logos é o que habita a alma. É no interior e não fora (dentro de nós e não em outro) que encontramos o caminho e os meios para nos decifrar tarefa em si mesma reconhecida por Heráclito como interminável: "Tão longo é o caminho da alma, e tão profundo o logos que ela retém, que jamais encontrarás os seus limites, percorrendo-o" (DK 22 B 45; cf. Diels \& Kranz, 1989).

Daímôn, na medida em que designa o que é divino em nós, é um correlato de theîon, contraposto da empiria, e, como tal, expressão do que é etéreo, do que só se deixa acessar racionalmente pela via do conceito. É divino tudo o que não é suscetível de percepção empírica, que apenas pode ser abstraído mediante a razão teórica. "As coisas divinas, dizia Demócrito, são conhecidas pela razão <phrenì theîa noûntai>" (DK 68 B 129; cf. Diels \& Kranz, 1989) ${ }^{25}$ De um modo geral, tudo o que hoje concebemos como a priori,

saggi (gnômas), e l'êthos divino cui invece essi sono reconosciuti, è certamente (secondo propone CL. RAMANOUX, Héraclite, pp. 319 e 418) opposizione di "maniere d'essere" o "disposizioni" delle due nature spirituali contraposte. Non pare invece accettabile (...) il vecchio senso di abitazione o redidenza... Il senso di indole, carattere, maniera d'essere o simili è confermato anche dalle interpretazioni antiche..." (ZELLER, \& MONDOLFO, R. 1967, p. 358, n. 67).

25 "são conhecidas - nénôtai"; nénôtai é a terceira pessoa do singular, perfeito passivo de noeîn = foi pensado ou concebido. 
transcendental, ${ }^{26}$ os gregos denominavam theîon, como uma "região" que se estende para além da empiria, e que, como tal, se subtrai ao conhecimento empírico. Os escolásticos, curiosamente, traduziram theîon por ex mundi ratione $<$ fora do mundo da razão $\rangle,{ }^{27} \mathrm{Com}$ o que subentendiam o seguinte postulado: nihil est in intelectu quod prius non fuerit in sensu <nada (chega ou) está no intelecto que antes não tenha (passado ou) estado nos sentidos $>^{28}$... Não sendo, pois, o daímôn uma entidade física, não existindo nem enquanto forma e nem enquanto grandeza, então é theîon (divino): uma dimensão do que é etéreo inerente à alma humana.

Também em Sófocles encontramos alguma ajuda quanto à vinculação entre êthos e daímôn. No Édipo em Colono, "retrato" do drama derradeiro de Édipo, Sófocles liga o destino de Édipo a daímôn (Édipo em Colono. vv. 136-137; cf. Sófocles, 1958). Sófocles deixa bem claro que Édipo, apesar de toda a sua tragédia e de suas desgraças, não se dispõe em momento algum a fugir de seu destino. Édipo enfrenta a si mesmo, e, em si, e por si mesmo gerencia o seu drama: "Aqueles (diz Sófocles - como se fossem palavras de um mântico) que desconsideram a medida e os limites humanos, que se deixam carregar pelos deuses, (...) duramente sucumbem no infortúnio, porque pretendem, com a ajuda dos deuses, elevar a natureza humana (ánthrôpou phýsin) para além da capacidade humana (ánthrôpon phronêi)" (Ajax. vv. 758-761; cf. Sófocles, 1958) ${ }^{29}$ Está contida nessas palavras de Sófocles a principal máxima que despertou e fortaleceu o filosofar: "Tenha coragem de ser homem, não queira ser um deus"! Alguém que se dispusesse a ser um deus desistiria de ser homem; e quem pelos deuses se deixasse

26 É necessário não confundi-lo com transcendente. Por transcendental, já entre os medievais, a começar por Duns Scot, denomina-se noções atribuídas ao ser, tal como, por exemplo, de res (de coisa) e de aliquid (de alguém, ou de algo). Os transcendentais são denominados por Scot de conceitos disjuntivos (Questiones Subtilissimae in Metaphysicam Aristotelis, pról., n. 5; Idem. Sec. VI, p.333). Tidos como unívocos, são devidos a uma única fonte: o intelecto. Nesse caso, não seria, pois, das coisas sensíveis que o intelecto (per quidditas rei sensibilis) retira todos os seus conceitos, e sim de si mesmo, porquanto a empiria se põe, para o intelecto, como principal motivação ("Tamen ei pro statu isto adaequatur in ratione motivi quidditas rei sensibilis, et pro isto statu non naturaliter intelliget alia quae non continentur sub isto primo motivo" - Opus Oxoniense. I, d. 3, q. 3, n. 24). A partir de Scot, Ockham adotou a mesma designação, e, mais tarde, Kant deu efetivamente ao termo a conotação que ainda hoje conservamos...

27 O que os levaram a fazer essa transposição foi o princípio epistêmico que adotaram. Acreditando que "nada está no intelecto que antes tenha estado nos sentidos" (nihil est in intellectu quod prius non fuerit in sensu), tudo o que não se submetesse a essa via, teria que ser ex mundi ratione. A adoção desse ponto de vista causou-lhes sérios problemas, sendo que a teoria do nominalismo de Duns Scot e de Guilherme de Ockham foi um tentativa de solucioná-los.

28 Fórmula com a qual Tomás de Aquino pretendeu sintetizar, mas, a bem da verdade, minimizou a teoria aristótelica do conhecimento.

29 Traduzimos phrónêsis por capacidade, no sentido da qualidade ou de uma aptidão da interioridade humana para a execução de um determinado fim. 
carregar, furtar-se-ia de enfrentar a si mesmo, e de gerenciar a própria vida. Daímôn, pois, vinculado à moîra, ao destino, se impunha como expressão desse enfrentamento: de um vigor (circunstanciado pela experiência vivida - tal como em Édipo) que, feito um hábito, vem de dentro e não de fora, se dá como um animus, que estimula a viver e a também concretizar (levar a cabo) a própria sorte.

C) O êthos vinculado à moîra. Moîra traduz-se por destino, termo que expressa não uma mera fatalidade, mas, sim, uma potência ou força constringente. Moîra emerge e se estende num tríplice significado: a) natural ou físico (nos termos da phýsis), ou seja, do que se constringe por natureza; b) deliberativo ou ético, do que se impõe mediante escolha ou deliberação; e c) fortuito ou casual, do que ocorre por acaso ou que advém como mera fatalidade.

Relativo ao item "a", ou seja, nos termos da phýsis: tudo o que nasce se orienta (sem violência e sem ser forçado) a partir ou por aquilo a que se destina, de modo que geração e destino, início e fim, coincidem. A phýsis diz respeito ao que é uniforme, tanto quanto ao que é essencial, e não ao que é aparente - nos termos, assim, como disse Ésquilo: "A natureza nos veste de formas diferentes <morphês d'ouch homóstolos phýsis>" (As suplicantes, v. 496; cf. Ésquilo, 1964). O nascer destinado, o estar em si mesmo dotado de um princípio de movimento pelo qual o que nasce cumpre o seu processo natural de geração e de realização, isso é a phýsis. Daí que phýsis não é expressão nem do anárquico (como disse Aristóteles: "não é possível que se dê uma ação anárquica de um ser em outro ser" (Física, I, 5, 188a 32-33; cf. Aristóteles, 1952) - não é possível, por exemplo, que lentilha dê feijão), e nem do ocasional ("no céu nada se faz por acaso" (Física, II, 4, 196b 3; idem, 1952), ou, acidentalmente); disse ainda Aristóteles: "não é o azar, mas a finalidade que reina nas obras da natureza", e, portanto, "é a finalidade que governa a constituição e a produção do ser" (Parties des animaux. I, 5, 24-27; cf. Aristóteles, 1995). O que a phýsis designa é o que ocorre sempre ou de ordinário, mas com uma eficácia tal que dispara sempre (como se fosse um gatilho biológico) o suposto como devido e necessário, tendo em vista "o melhor dentre todo o possível" (Tratado sobre o Céu, II, 5, 288a; cf. Aristóteles, 1986).

Quanto ao item "b", ou seja, nos termos do arbítrio ou da deliberação humana, moîra também diz respeito a uma potência diretiva, mas decorrente de um governo ou necessidade auto-regulativa, em sentido antropológico, não cosmológico. Essa potência, que exercita a constrição, pode derivar seguramente de duas fontes: ou da vontade de um indivíduo, que constrange a si mesmo, ou, das leis do Estado, que constrangem a todos. Como diziam os pitagóricos: "o destino é a causa do ordenamento das coisas, tanto 
do conjunto como de suas partes" (DK 58, Escola pitagórica, B 1a, 21; cf. Diels \& Kranz, 1989), em que "tudo é produzido (segundo palavras do pitagórico Filolau) por necessidade e harmonia" (DK 44 A 1, 11; cf. Diels \& Kranz, 1989). Moîra, sob esse aspecto, se vincula ao mundo humano, à capacidade humana de vislumbrar, para si ou para o todo, o suposto como melhor e necessário, dentre o possível (o tôn beltístôn praktikê, o "agir do melhor modo", de que fala Aristóteles na Ética a Nicômaco (II, 3, 1104b 25; cf. Aristóteles, 1984). No Cosmos, toda a determinação se dá espontaneamente; no mundo humano carece de empenho e de deliberação: atitudes que requerem exercício racional, instrução e educação. Caberia ao destino corresponder à necessidade, ${ }^{30}$ e, ao logos, ser a essência dessa destinação. ${ }^{31}$ Dá-se que a edificação do ser-homem, na medida em que busca o dever-ser, só se deixa satisfatoriamente realizar no contexto de sua própria da experiência, e mediante o exercício do logos racional.

Relativo ao item "c", em que moîra expressa o acaso, remonta a Homero essa vinculação: "Não há homem (disse ele) que possa evitar o seu destino <moîra>". ${ }^{32}$ Heráclito, um pouco mais tarde, mirando-se nos pitagóricos, disse algo semelhante: "tudo advém conforme o destino...". ${ }^{33}$ Homero deu à sua afirmação um sentido particularmente antropológico, e pôs acento no inevitável, no que na vida humana se impõe feito uma fatalidade; o dizer de Heráclito se aplica tanto ao homem quanto ao Cosmos, e com ele realçou o conceito de conformidade ou mediação (katá). Por um lado, ele pressupôs (sob o termo destino, no sentido da kath' eimarménên) um princípio de determinação natural, mediante o qual tudo o que existe se move em vista de uma direção; por outro (em sentido antropológico), que ao homem só é plausível se mover por deliberação, ou seja, mediante um exame ou inspeção interior que põe à mostra, e que, enfim, se conforme com as necessidades (limites e possibilidades) próprias da natureza humana.

Somos dotados, essa é a questão fundamental ali suposta por Heráclito, de contradições, que carecemos de harmonizar, de com elas edificar o nosso próprio kósmos. O primeiro passo, entretanto, seria conhecê-las; o segundo, decifrar a nós mesmos, ou seja, compreender a nossa constituição natural, o archétypon que está no móvel, e na origem (na archê) de nosso modo próprio de existir. Seria em dependência desse cifrar a nós próprios [nos termos como disse ter feito Heráclito: "Eu me procurei a mim mesmo"

30 Aécio. Opiniões, I, 27, 1; DK 22 A 8.

31 eimarménên dè lógon (Aécio. Opiniões, I, 28, 1; DK 22 A 8); Aécio. Opiniões, I, 7, 22; DK 22 A 8.

32 Escólio à Ilíada, XVIII, v. 251; DK 22 B 105; Iliada, VI, v. 488.

33 pánta dè gínesthai kath'eimarménên... (Diógenes Laércio, Vidas e Doutrinas dos Filósofos Ilustres, IX, 7; DK 22 A 1, 10). 
(DK 22 B 101; cf. Diels \& Kranz, 1989) ${ }^{34}$ ], que deveríamos fundar o nosso êthos. Ocorre que, de nossa phýsis (de nossas disposições naturais) não podemos fugir, porque a nossa natureza é nosso daímôn: um vigor inerente à alma que nos impõe limites e contradições, enquanto faculta possibilidades. Desse vigor, na medida em que nos dispomos a ser o que devemos ser, ou seja, homens, não podemos nos esquivar. Eis aí porque, em sentido amplo, na expressão de Heráclito, e, antes, na de Homero, ninguém está imune ao seu destino...

Não podemos esquivar de nosso destino, porque temos, como indivíduo humano, consoante à nossa espécie ou gênero (portanto, dentro de nós), uma pré-disposição natural (feito impulsões de um movimento de vida) que a todos nós dispõe em vista do que é preciso ser. Carecemos, com efeito, de seguir o ritmo de nossa própria natureza; algo, todavia, que nos cabe fazer sem contenção demasiada (sem uma rigorosa luta contra nós mesmos), e sem repressão desmedida; não, porém, sem esforço interior (sem contensão), e sem aplicação do logos ou dos recursos de nossa mente. Ocorre que o nosso modo de ser, e, inerente a ele, o nosso modo de habitar o kósmos e a pólis, porquanto careça de experiência, não pode ser apenas derivado dela, e, tampouco, retirado artificialmente dos mitos, das crenças e dos costumes tradicionais (forjados pela imaginação, e na experiência). Precisamos pôr em marcha o exercício do pensar. Na realização dessa tarefa, o pressuposto de nosso relativo sucesso está, primeiro, em nos contentar em ser homem: descartar o sonho descabido de querer ser um deus. Para o que só temos uma saída: "conhecer a nós mesmos". Ao que se impõe a moderação. Claro que a experiência do viver nos põe a percepção de nossas possibilidades e de nossos limites. Com efeito, é somente a razão, o exercício noético, que, inevitavelmente, nos leva a aprender a lidar com eles, e nos ensina a considerar, frente a eles, a justa medida: nem para mais, nem para menos. Por isso a moderação: o aprender a não se exceder, a cultivar o equilíbrio (o "nada em demasia"), a fim de, satisfeitos, vivermos dentro dos limites e das possibilidades de nossa própria natureza.

Ainda relativo ao conceito de moîra (de destino), Sófocles (496-406 a.C.), com a sua dramaturgia, particularmente com a tragédia do Édipo Tirano (Oidipus Tyrannos, traduzido pelos latinos de Oedipus rex ${ }^{35}$ ), foi sem

34 edizêsámên emeôutón - conservado por Plutarco, Contra Colotes, 20, 1118c.

35 A tradução de Týrannos por Rex se explica facilmente: em razão de que a tirania imperava em Roma sob o título de reinado. Naquela ocasião, o imperador romano era um tirano que só se contentava com o título de rei. 
dúvida o que mais dramatizou o pressuposto segundo o qual nenhum homem pode livrar-se de seu destino. Esse princípio (que vale tanto para a explicitação do que vem a ser a phýsis e do que vem a ser o êthos) se sedimentou de tal modo na cultura grega, a ponto de se tornar um fenômeno essencialmente religioso. Foi bem assim que Sófocles, no Édipo Tirano, o descreveu: como se o destino configurasse um mandado dos deuses. Tão incisivo que só eles, por beneplácito próprio, independentemente de qualquer sacrifício ou súplica, eram capazes de revogar. Os deuses, na opinião de Sófocles (que, aliás, será a mesma de Epicuro, dentro, porém, de uma configuração distinta) só fazem o que querem, porque acham que devem, a ponto de nenhum mortal ser capaz de dissuadi-los (coagi-los) a fazer o que não querem. Ésquilo, nas Suplicantes, justificou assim esse querer incontido dos deuses: porque eles não se cansam, ou seja, porque "nada custa trabalho a um deus" (As suplicantes, v. 97; cf. Ésquilo, 1964). ${ }^{36}$

Sófocles, relativo à questão da moîra, nada reduz à pura fatalidade ou à pré-determinação: como se as disposições do acontecer fossem apenas vontade de um deus. É na consciência de si, na medida em que o indivíduo toma conhecimento da realidade dentro da qual está inserido, que o seu destino adquire sentido (e que, por suposto, nos tiraniza). Por esse ponto de vista, o Édipo Tirano de Sófocles veio a ser o bom exemplo. Sófocles, em seu poema, descreveu Édipo acometido de dois momentos de cegueira: um, antes da tomada de consciência (aquela mediante a qual Édipo identificou a si mesmo com seus feitos: o ter matado um indivíduo, que, afinal, era o seu pai, e o ter se casado com uma mulher, que era a sua mãe); outra, a tomada de consciência depois dessa identificação: aquela em decorrência da qual o rei Édipo cega a si próprio, com uma intenção bem precisa, qual seja, jamais ver no olhar dos outros a identificação constante de seus nefastos crimes (o parricídio e o incesto, por ele cometidos).

Depois de cego, de ter cumprido abomináveis feitos, Édipo volta a ser errante: de início acabou em Corinto e deixou Corinto para fugir (se pôr fora da rota) de seu destino; agora, é expatriado de Tebas, busca asilo em Colono, na Ática, (como que) para fugir de si mesmo. "É agradável desalojar a alma da consciência de seus males!" (Édipo rei. vv. 1389-1390; cf. Sófocles, 1958). É doce, quando tomados por inquietações e agonias, afastar-nos de nós mesmos. Dentro de nós está a nossa permanente morada (a nossa oikía), e é dela que de várias maneiras tentamos umas quantas vezes fugir: ausen-

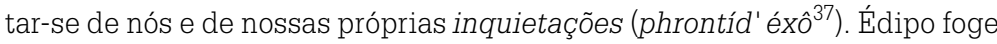

36 pãn áponon daimónion.

37 Phrontíd' éxô expressa a ideia de um pôr-se fora da reflexão: um des-reflexionar. Phrontís diz respeito ao cuidado, expressa a preocupação e a inquietude consigo mesmo. 
de tudo como quem foge de si. Mas, o tempo impiedoso, aquele que devagarinho nos vai matando, traçando a nossa história e confeccionando a nossa própria sorte (tempo todo-poderoso, pagkratês chrónos, ${ }^{38}$ tal como o supôs Sófocles), fez dele, antes, um rei, agora, apenas um homem domesticado <Oidípoun kath'hêméran ${ }^{39}>$ : conformado com a própria sorte, "civilizado" por sua particular experiência de vida e tiranizado pelo seu destino.

Houve, sim, em Édipo uma inquietação reflexiva, um tomar ciência de si, mas isso se deu como um fenômeno progressivo: ele sempre soube que, na estrada, matara um homem, mas não sabia que esse homem era o seu pai; ele estava ciente de ter se casado, não exatamente por amor, mas por conveniência, ou seja, para ascender ao reino, porém, não sabia que ao se unir com tal mulher, tinha se casado com a sua própria mãe. Se ele tivesse tido conhecimento prévio desses fatos, teria bem provavelmente posto limites em sua ação. Jamais teria feito o que fez: efetivado dois crimes tão sórdidos que nem sequer carecem da lei para serem condenados. Édipo, antes de efetivar seus crimes, não tinha muito que fazer, a não ser fugir do sórdido destino, do qual estava avisado (por um oráculo de Apolo). Depois, assim que tomou consciência de seu feito, ou seja, assim que identificou o seu destino (não propriamente a si mesmo) com a sua ação, buscou fazer o que caberia a um homem fazer: a) vincular a sua vontade ao seu destino, a fim de agora enfrentá-lo e de doravante realizar os seus desejos dentro de certos limites ou de certa consciência; b) confrontar-se consigo mesmo e escolher o melhor caminho a seguir; c) julgar a si mesmo a partir ou mediante seu próprio olhar e não pelo olhar dos outros.

Se Édipo, desde o início, tivesse tido consciência de seu destino, se ele tivesse, previamente, exercido a capacidade de se autodeterminar (se a sua consciência forjada depois tivesse se imposto antes da ação), ele teria tido grandes chances de agir de outro modo. Todavia, não se deu assim, mas deste modo: por um lado, foi a ação que o capacitou a ser a si mesmo (se não tivesse feito tudo o que fez, não seria o Édipo); por outro, na carência de uma autoconsciência sem a ação, de uma autodeterminação prévia, anterior ao agir, ele então acabou sendo vítima (mais do que de insólito) de imponderáveis da vida...

Laio, o seu pai, tendo ciência do oráculo de que seria morto por seu filho, tomou cedo a decisão de se desfazer do perigo: ele mesmo não matou,

\footnotetext{
38 "Os sofrimentos e a experiência de tantos anos (diz ele, no fim da vida), bem como a minha natureza corajosa, me ensinaram a resignação" (SÓFOCLES. Édipo em Colono. vv. 6-8); ou ainda: "só os deuses estão livres da velhice e da morte; tudo o demais é abrangido pelo tempo todo-poderoso" (SÓFOCLES. Édipo em Colono. vv. 607-609).

39 SÓFOCLES. Édipo em Colono. v. 3
} 
mas mandou que matasse o seu próprio filho. Jocasta, a mãe, resignada, entregou o filho para a morte, mas ele sobreviveu, graças a um caminheiro (pastor de ovelhas), que o levou para bem longe, para outro reino: o de Corinto. Lá em Corinto, Édipo cresceu e foi adotado como filho e sucessor do rei. Também ali, ao tomar ciência do oráculo de Apolo, temeroso de que poderia matar o seu pai (para ele, o rei de Corinto, Políbio) e de se casar com a mãe (com Mérope, esposa de Políbio), Édipo foge de Corinto para Tebas. É nesse percurso que, na estrada, em uma desavença aparentemente banal, mata Laio, para ele um desconhecido. Em Tebas, casa-se com Jocasta, a viúva do rei, e assim se torna o outro Laio, ${ }^{40}$ ou seja, ascende ao reino.

Édipo não veio a ser um tirano porque simplesmente usurpou o poder, ou porque foi opressor, cruel e injusto para com o seu povo. Algo de inusitado lhe ocorreu: foi o destino que abusou dele, que impôs sobre ele a impiedade, tiranizou a sua vida, e isso sob a autoridade e a ciência dos deuses, em particular de Apolo, do patrono de Delos, deus de múltiplos poderes, e que nada fez. Sófocles não filosofa sobre essa questão, entretanto a Filosofia nasceu e se desenvolveu movida por semelhante empenho: desqualificar e transformar o pressuposto da destinação cruel. Os filósofos buscaram, primeiro, entender e demonstrar que a destinação (cruel) tem validade no que concerne ao movimento da gênese ou da phýsis, mas não no que diz respeito às determinações do viver. Uma coisa são as nossas determinações físicas naturais (da gênese) que nos impõem um dever-ser relativo ao qual não temos muito como fugir (nos deparamos com muitos riscos e sérias dificuldades ao queremos nos livrar de nossa própria sorte física); outra coisa bem distinta são as determinações adequadas à nossa natureza humana de ser (próprias de nosso gênero ou espécie), que nos impulsionam, e que, em nós, despertam a nossa natureza racional em busca de um dever-ser de outra ordem. É bem verdade que a nossa natureza humana nos limita, todavia é nela que encontramos o universo de nossas possibilidades. Ela, por exemplo, não nos impõe qualquer vício ou virtude, mas nos dispõe e constrange a certos vícios ou virtudes...

40 A figura feminina de Jocasta encerra de algum modo a condição da mulher no contexto da vida grega. Nesse caso (no fato de Édipo se casar com ela, a fim de ascender ao trono de rei) podemos compará-la à figura de Penélope (mulher de Ulisses) com a qual Homero descreveu, de modo muito expressivo, a situação da mulher (proeminente) na vida social dos gregos... A mulher era dada em casamento num contexto de manutenção, expansão e até mesmo aquisição de riqueza e de poder. Casada, ela passava a deter autoridade familiar, de certa maneira isolada da autoridade social do marido. Morto, porém, o marido, ela herdava formal e legitimamente a posse de sua riqueza e o seu poder (mesmo que não o exercitasse)... Foi, pois, por essa razão que, morto Ulisses, todos queriam se casar com Penélope, porque casando-se com ela, seriam o outro Ulisses, colocar-se-iam no lugar dele, assumiriam a sua riqueza e o seu poder... Foi o que fez Édipo casandose com Jocasta.... 
Daí, enfim, a questão: há em nós uma natureza que nos induz, sem nos determinar, a certo modo de ser; trata-se, com efeito, de um movimento em nós que requer atenção e diligencia (o "conhecer-se a si mesmo") a partir de nós ou da índole própria de nossa natureza humana. Quem faz o que deve sem esforço, e sem saber o que faz, carece de mérito. Frente a esse movimento, e como já posto, nós só temos uma saída, a exemplo do que o próprio Heráclito diz ter feito (atitude, aliás, que resume a autárkeia de Epicuro): "Eu me procurei a mim mesmo" (DK 22 B 101; cf. Diels \& Kranz, 1989). É na medida, pois, em que, deliberadamente, fazemos de nós mesmos sujeitos e objetos de nosso próprio estudo, que nos tornamos aptos para nos debater com o nosso próprio destino; destino que não nos é dado por natureza, mas facultado por ela, e que, por ela, nos limita na direção e na autodeterminação de nosso modo humano (próprio) de ser. Mas ainda resta um pequeno detalhe: por mais que nos empenhamos em nos autodeterminar antes da ação, só somos capazes de nos auto-identificar (ser a si mesmo) depois da ação. O fato é que não há como "procurar a si mesmo", e, por suposto se encontrar, isolando-se, do mesmo modo como é inalcançável a plenitude de consciência sem a ação, sem a vivência. Não dá para ser a si mesmo, e assim ser feliz, sem agir: sem, em nome de certa consciência, executar uma certa iniciativa.

\section{Lucrécio e Cícero: mores e consuetus}

De Homero a Aristóteles os termos êthos e éthos adquiriram vários significados em decorrência do uso que os filósofos e os poetas fizeram e dos atributos que adicionaram. De um modo geral, ambos detiveram as mesmas significações, e, na medida em que, sob uma ou outra grafia, adquiriram novos modos de dizer, transferiram um para o outro, resultando, por grafias distintas, numa mesma questão. Ambos foram quase sempre concebidos em relação à aretê (quer da pólis ou demos, quer do génos) em referência à qual expressavam um animus: um certo feitio ou disposição interior que movia e caracterizava (dava caráter) a uma certa coletividade. ${ }^{41}$

Também os latinos evidenciaram a distinção entre éthos e êthos concebida pelos gregos. O éthos (com epsílon), eles o traduziram por suetus,

41 Por coletividade entende-se um povo, uma pequena comunidade ou grupo familiar (pólis, demos ou génos) em referência aos quais existem qualidades cumulativas que caracterizam (referidas ao todo ao qual o sujeito pertence), atitudes e sentimentos que marcam realizações ou manifestações culturais de indivíduos particulares. A aretê, enquanto vigor ou animus pressupunha sempre uma qualidade, talento ou mérito entendido como uma excelência adquirida: ou por natureza, ou por um fazer (poíêsis) sob os aspectos prático e teórico: existencial, manual e intelectual. 
termo que resultou em português no nosso consueto (no que é tido como costumeiro, usual, corriqueiro); já o êthos com eta (certamente por influência de Aristóteles) verteram-no em mos, moris: termo que deu origem ao que, no tempo deles, digamos, de Lucrécio e de Cícero, veio a ser denominado de moral. "Tudo o que (de valioso) pertencia aos costumes (ad mores) os gregos denominavam de êthos; de nossa parte preferimos denominar de filosofia dos costumes (philosophiae de moribus), mas, se quisermos qualificar a língua latina, convém chamar de moral (moralem)" (De fato. I, 1; cf. Cícero, 1950). ${ }^{42}$

Por moral (mores) em sentido amplo, os latinos entendiam o cultivo do caráter, (cultivo das "boas" qualidades cívico-patrícias), e, não, a rigor, uma disposição ética no sentido de promover princípios racionais orientadores da conduta de excelência. Cícero faz uso do termo mores a fim de expressar a) o caráter, a índole ou o gênio diversificado de cada um; ${ }^{43}$ b) os costumes (no sentido de "o que é valioso") que promovem, junto ao caráter, o elã das relações em vista "da congregação e da comum sociedade do gênero humano" (De finibus, IV, III, 5; cf. Cicero, 1999). ${ }^{44}$ Além do termo mores, Cícero se vale também de virtutis e honestatis, com os quais indica, em sentido ético, o exercício do caráter (a prática do que é valioso na ação), e, por ele, o que é equitativo: reto, justo, etc. ${ }^{45}$ Isso em harmonia com a virtus, ou seja, com o que ele denomina (sob um ponto de vista estoico) de factis illustribus et gloriosis: "ações ilustres e gloriosas", isto é, de excelência, que, sobretudo, são executadas em vista delas mesmas, e não em função da felicidade ou satisfação que elas promovem. ${ }^{46}$

42 "... quia pertinet ad mores, quod êthos illi vocant, nos eam partem philosophiae de moribus appellare solemus, sed decet augentem linguam Latinam nominare moralem". O entre parênteses foi acrescentado.

43 varii mores, digamos, em português, os vários temperamentos (CÍCERO. De finibus, II, III, 10); mores naturasque - caráter ou índole natural (CÍCERO. De fato. I, 10).

44 "... ad congregationem hominum et ad societatem communitatemque generis humani". No mesmo livro IV (XXII, 61), se vale do termo mores num sentido restrito de costumes - ac mores civitatum; o mesmo no livro V, IV, 11: ab Aristotele mores (...) cognovimus - através de Aristóteles conhecemos os costumes.

45 De finibus, I, 25, 36, 57, 62; no decorrer do II, a começar pelo VI, 19 e seguintes.

46 CÍCERO. De finibus, I, XI, 37; XIII, 43; XVI, 54. Este é um ponto em relação ao qual os estoicos e os epicuristas divergem profundamente... Do ponto de vista epicurista a ação moral pressupõe ações concretas em favor do sujeito agente. O sujeito age sempre em vista do benefício próprio ou em favor de si mesmo. É esse benefício que se reverterá finalmente em ação moral. Ela é moral porque atinge positivamente os outros de minha relação. Se, por exemplo, eu vivo em tudo com moderação (algo que faço em vista de minha felicidade ou bem estar próprios) reverte em favor do todo, isto é, da comunidade de minhas relações ou de minha aderência. Se como com critério e moderação, isso reverte em saúde própria, em bem estar, e, no fim, reverte positivamente em favor da comunidade; se bebo com moderação, etc., isso é bom para mim e também para os de minha relação, para os quais seria sob vários aspectos odioso conviver com o meu alcoolismo, etc. etc. 
Lucrécio, contemporâneo de Cícero, recorreu ao termo mores, a fim de denominar o que concebeu por mores generatim, isto é, por usos ou costumes próprios de uma geração, que, transladados e reproduzidos no tempo (por imitação dos filhos aos pais), vinham a construir o mores victum motusque parentum: os usos e os costumes próprios de um movimento de vida parental. ${ }^{47}$ Ele comparou o que denominou de "auras vitais - vitalibus auris"48 (expressão com o qual quis indicar as estratégias de que se servem as espécies para se proteger e conservar), com o "mores generatim - os hábitos ancenstrais", da geração. ${ }^{49}$ A vitalibus auris ele a definiu como sendo "a astúcia, o vigor e a mobilidade - dolus aut virtus aut mobilitas" das espécies, disposições com as quais preservam o princípio natural da reprodução da vida (a descendência física); sobre o mores generatim disse as mesmas coisas, porém deu a dolus e à virtus o sentido de uma força e astúcia cooperativas, mediante as quais um certo grupo preserva os liames relativos aos modos de ser e de agir próprio de sua parentela (de sua gênese natural e de sua ancestralidade).

O conceito de mores generatim, Lucrécio não o aplica só aos humanos, mas também a todas as espécies animais. Os bois, os cavalos e as ovelhas (disse ele) pastam as mesmas ervas, vivem sob o mesmo Céu e matam a sede com as mesmas águas, porém "conservam a natureza de seus pais (parentum naturam) e imitam os hábitos de sua espécie (mores generatim imitantur)". ${ }^{50}$ Mores, nesse contexto, expressa, sobretudo, um distintivo, mediante o qual, e ao mesmo tempo, põe à mostra diferenças (relativas aos demais) e semelhanças (relativas ao grupo). O mores humano corresponderia, pois (sob um ponto de vista epicurista), à própria natureza humana, com as especificidades que lhe são inerentes. Com efeito, na medida em que o mores designa o que põe à mostra certa habilidade ou astúcia, tal mobilitas não advém de puro mérito natural, porque também de vigilância exercitada na estratégica, em dependência da qual a parentela preserva seus próprios hábitos em vista das realizações de seus próprios fins (dentre os quais o da felicidade é o supremo).

47 "nec totiens possent generatim saecla referre/ naturam mores victum motusque parentum"; "dissimili vivont specie retinentque parentum/ naturam et mores generatim quaeque imitantur" (LUCRÉCIO. De rerum natura. I, vv. 597-598).

48 LUCRÉCIO. De rerum natura. V, v. 857ss.

49 "dissimili vivont specie retinentque parentum/ naturam et mores generatim quaeque imitantur" (LUCRÉCIO. De rerum natura. I, vv. 664-665).

50 "Saepe itaque ex uno tondentes gramina campo/ lanigerae pecudes et equorum duellica proles/ buceriaeque greges eodem sub tegmine caeli/ ex unoque sitim sedantes flumine aquai/ dissimili vivont specie retinentque parentum/ naturam et mores generatim quaeque imitantur" (LUCRÉCIO. De rerum natura. II, vv. 660-665). 
Lucrécio se serve outras vezes do termo mores: no livro I, inerente à expressão sollemni more sacrorum, concede a more o sentido de costumes ou ritos, nos termos de uma prática ou procedimento, ${ }^{51}$ do mesmo modo no livro II, sob a expressão "antiquo more sacrorum - segundo os antigos costumes sacros", 52 em que more é suposto como uma atitude (nos termos de uma fidelidade) em vista da qual se erige um certo tipo de relação. No livro VI, Lucrécio atribui a more o sentido de feitio, de maneira ou modo de ser: o Sol (relata) deu muitos giros na abóbada celeste, durante o tempo em que os homens, "errantes, arrastavam a vida feito animais selvagens (more ferarum)". ${ }^{53}$

More (quer em Cícero, quer em Lucrécio) não corresponde, em sentido próprio, nem a uma autoridade nem a uma lei, mas isso não quer dizer que seja destituído de autoridade, e, tampouco, deixa de ter (tacitamente) força de lei. ${ }^{54} \mathrm{O}$ termo mores, em sentido amplo, dizia respeito a um domínio (nos termos de uma autoridade ou poder), mas não propriamente derivado de uma imposição; não sendo a rigor natural, o domínio ao qual o mores se refere, condiz com um modo de ser e de viver, ${ }^{55}$ em dependência do qual um indivíduo particular é identificado perante um grupo (família, povo ou nação) do qual faz parte. Daí por que, nesse sentido, mores <êthos> é sinônimo de consueto <de éthos>: daquilo que é característico e predominante nas atitudes e sentimentos que marcam as realizações ou manifestações culturais de uma comunidade (grupo ou nação). É por elas que os indivíduos se identificam com os de suas relações (atuais e antepassadas): com aqueles aos quais conservam e expõem (uma vez isolados) frente aos de-

51 LUCRÉCIO. De rerum natura. I, v. 96. Agostinho da Silva traduziu assim: "solenes ritos sagrados"; Alfred Ernout, "les rites solennels"; Eduard Valentí Fiol, "el rito solemne".

52 "Hanc variae gentes antiquo more sacrorum..." (LUCRÉCIO. De rerum natura. II, v. 610).

53 "Multaque per caelum solis volventia lustra/ volgivago vitam tractabant more ferarum (LUCRÉCIO. De rerum natura. V, vv. 931-932). O mesmo, ele repete no livro VI: Os ventos, com grandes rugidos, "nos ameaçam feito feras enjauladas - in caveisque ferarum more minantur" (LUCRÉCIO De rerum natura. VI, v. 198).

54 "Dá-se que a fé nos deuses não foi imposta nem por uma autoridade qualquer, nem por um more e nem por uma lei, mas está fundada sobre o unânime consenso de todos - Cum enim non instituto aliquo aut more aut lege sit opinio constituta maneatque ad unum omnium firma consensio..." (CÍCERO. De natura deorum, I: XVII, 44).

55 Citando Ênio, que dizia serem os macacos muito semelhantes a nós, Cícero concorda, mas acrescenta que "entre um e outro, a disparidade está no mores", termo com o qual aqui queria expressar um modo de ser - "... Ennius, 'simia quam similis turpissuma bestia nobis'; at mores in utroque dispares". Porém, logo na sequência, faz uso do termo mores, a fim de expressar apenas o caráter: "e, entre os homens, não encontramos inúmeras e semelhantes formas com caráteres díspares, e, inversamente, semelhantes caráteres com aparências diferentes? - quid, inter ipsos homines nonne et simillimis formis dispares mores et moribus [paribus] figura dissimilis?" (De natura deorum, I, XXXV, 97). 
mais características próprias, consuetudinárias, que, enquanto unificam, fazem emergir diferenças..

Mores e consuetus, na literatura latina, são, pois, dois termos que se explicam reciprocamente. Quando, de um modo geral, os latinos diziam suetu (consuetu, consuetudine) eles se referiam ao que estavam acostumados, como tal adotado em decorrência de uma usança ou hábito (héxis, para os gregos) tradicionalmente reconhecido como válido, tido ao mesmo tempo como bom ou certo, como devido ou eficaz. ${ }^{56}$ Seria consueto, por exemplo, o que os nossos antecessores veneraram com solenidade e devoção, e que a ele aderimos; ou ainda, o que (em si mesmo dotado de sabedoria) foi reconhecido e expressamente comunicado por nossos antecessores como valioso, e que pede por alguma reverência ou respeito.

"É um mau e ímpio costume (mala et impia consueta, dizia Cícero) discursar contra os deuses, seja por convicção, seja por mero pretexto" (De natura deorum, II, 168; cf. Cícero, 2000). ${ }^{57}$ Consueto seria, pois, o que define certa comunidade de relações, como tal um qualificativo da alma de um certo grupo ou povo. É consueta, por exemplo, aquela alma que se rege por uma herança do passado, por, digamos, o que é histórico, tradicional, duradouro, transladado de geração em geração, e que, sob essa condição, é reconhecido como digno de valor. ${ }^{58}$ Trata-se, com efeito, de um hábito imbutido na alma quer de um indivíduo particular quer de uma coletividade ou de uma cultura. Foi por certo nesse sentido que Cícero definiu à consuetudine de moribus domesticis, de costumes domésticos (hábitos dos de casa). ${ }^{59}$

Lucrécio, ao relatar a antiga crença popular dos latinos de que os leões não suportam ouvir o canto do galo, se vale do consuetum, a fim de expressar o que ocorre de ordinário, regularmente, dentro de uma ordem corriqueira, usual. Eis o que ele diz: que leões fogem "do galo, quando, com sua voz clara, aplaudindo com as asas a partida da noite, invoca, como de costume, a aurora"; um pouco mais adiante, Lucrécio se vale de consueto, a fim de realçar uma pertença (ou pertencimento) a um domínio dentro do qual algo está pacificamente integrado. Depois de descrever que os cães de caça às vezes perseguem, em sonho, simulacros de veados, relata que até na

56 Cícero, por exemplo, no De Finibus, se vale do termo consuetudine, a fim de designar o usual: por exemplo: no livro I, XX, 69, se serviu do consuetudinum e de consuetudine, a fim de expressar algo com o que se institui uma aproximação, cria hábitos, forja relações; no livro II, X, 30, refere-se ao emprego usual das palavras - consuetudinem verborum; no mesmo livro II, XIV, 48 se valeu de consuetudo loquitor, a fim de designar o linguajar ordinário, corriqueiro; ARISTÓTELES. Ética a Nicômaco. IV, 4, 1125b 20; IV, 5, 1126b 5.

57 "Mala enim et impia consuetudo est contra deos disputandi, sive ex animo id fit sive simulate".

58 CÍCERO. De natura deorum, II, 69.

59 CÍCERO. De natura deorum, II, 74. 
"meiga raça dos cãezinhos de estimação", habituados à casa, isso também ocorre (De rerum natura. IV, vv. 710-713, 997; cf. Lucrécio, 1985). ${ }^{60}$ Consueto, em outro verso, tem o sentido de algo imposto como um hábito em decorrência da necessidade imposta por um modo de ser: o homem desmata e cultiva a terra, mas, se não teimasse, se não fosse "habituado a gemer sob o enxadão <consueta bidenti ingemere>", a natureza tudo voltaria a esconder sob o matagal. ${ }^{61}$ No livro VI, encontramos igualmente consueto no sentido de modo de ser: "Existe, inclusive (relata Lucrécio), nos grandes montes do Helicão, uma árvore capaz de matar um homem com o habitual repugnante odor de suas flores" (vv. 786-787 - cf. idem, 1985). ${ }^{62}$ Falando, enfim, da pedra imã, Lucrécio recorre novamente a consueto para salientar uma regularidade, um movimento ou "agir", que, de tempos em tempos, se repete como se fosse um hábito, conformado (regrado) por certa realidade ou modo de agir (e, por suposto, de reagir): "às vezes, a substância do ferro se distancia da pedra por uma alternância regular (consueta) de atração e repulsão". 63

O consuetus latino comportava, por um lado, o significado de o que é seu, no sentido de algo dado, herdado como propriedade, e que, justo por isso, vinha inevitavelmente a se tornar familiar; por outro, e em vista dessa familiaridade, desse tornar-se como que doméstico, se impunha (se consignava) como um hábito, a exemplo de como se referiu Lucrécio à progenitura do amor: o hábito harmoniza o amor - consuetudo concinnat amorem" (De rerum natura. IV, v. 1283; idem, 1985). Concinnat (de concinno) exprime a ação de arranjar, de dispor, de proporcinar bem alguma coisa em vista do que é devido (no caso, o amor). Por Lucrécio, aqui está dito que é a consuetudo que promove esse arranjo, e com isso quis dizer uma concretização (realização ou efetivação) dada no tempo, quer ajeitando-se numa retrospectiva consuetudinária [é próprio dos casais buscar a harmonia entre si, e, juntos, mas também cada um, com os membros da nova família, com seus usos e costumes], quer harmonizando-se numa perspectiva de futuro. Daí que o que Lucrécio denomina aqui de consuetudo, expressa, de modo pró-

60 Respectivamente: "Quin etiam gallum noctem explaudentibus alis/ auroram clara consuetum voce vocare,/ noenu queunt rapidi contra constare leones/ inque tueri..."; “... at consueta domi catulorum blanda propago".

61 "Quod super est arvi, tamen id natura sua vi/ sentibus obducat, ni vis humana resistat/ vitai causa valido consueta bidenti/ ingemere et terram pressis proscindere aratris" (LUCRÉCIO. De rerum natura. V, vv. 206-209).

62 Daria para dispensar a tradução de consueto: "Est etiam magnis Heliconis montibus arbos/ floris odore hominem taetro consueta necare".

63 "Fit quoque ut a lapide hoc ferri natura recedat/ inter dum, fugere atque sequi consueta vicissim" (LUCRÉCIO. De rerum natura. VI, vv. 1042-1043). 
prio, o que os filósofos gregos denominavam de héxis, termo com o qual eles definiram, em última instância, a vida ética.

Na Física, Aristóteles concebeu a héxis não como uma alteração (alloîôsis), mas, sim, como um acabamento (teleíôsis) e como uma elevação interior (ekstásis). ${ }^{64}$ Como acabamento (teleíôsis), a héxis foi por ele concebida tanto como uma inclinação natural, espontânea, decorrente do modo humano de ser, quanto como uma motivação adquirida, imposta pela lei ou pelo consuetudinário, em vista de um determinado modo de agir e de um fim; a héxis como ekstásis é a filosófica: aquela que requer educação racional, a fim de que o sujeito agente reflexione o seu agir (submeta-o a uma consciência derivada de uma ideia racional do dever). Mas tanto no sentido da teleíôsis (da proposição de fins) quanto da ekstásis (da elevação frente ao empírico e do recolhimento interior), a héxis é tida como uma disposição de ânimo: comporta um sentido de colocar-se numa posição devida em vista do melhor, do mais justo, mais adequado, etc.. É por esse dispor-se do sujeito (do agente cívico) que Aristóteles define a héxis: como uma inclinação em vista de uma certa maneira relativa de ser, de portar-se ou de fazer condizente à execução de interesses ou necessidades quer em favor do agente (para consigo mesmo) quer para o bem comum da Pólis.

Traduzida, em geral (pelos latinos), por habitus, a héxis dos gregos veio a ser expressão de um movimento relativo ao fazer, como tal uma virtus (vigor ou ação), no sentido de uma eficácia que sempre tem como móvel o melhor possível. Não se trata, todavia, de um fazer isolado, mas inerente a certo modo (de agir e de pensar) que se vai apropriando mediante exercício, e do qual, lentamente, se vai tomando posse, e por ele se dispondo a um novo estado de ânimo como um bem adquirido. "É se exercitando (ensinou Aristóteles) sobre o que a cada um diz respeito, que nascem as héxeis (os hábitos ou as disposições)" (Ética a Nicômaco. III, 5, 1114b 10; cf. Aristóteles, 1984). É por esse exercitar-se que nasce a experiência consolidada, manifesta como possessão ou domínio em que se reconhece dotes de excelência, tão valiosos que alcançam a conotação de virtude (validada pela comunidade familiar, pela oikía, e pela Pólis), e em dependência dos quais os indivíduos "amoldam" ou dispõem o caráter.

"A virtude (escreveu Aristóteles) é uma héxis (uma disposição) que nos inclina a ser a mesótês (o meio termo) que nos convém" (Ética a Nicômaco. II, 6, 1106b 36; cf. Aristóteles, 1985); e acrescenta: "nós a denominamos de

64 “... os hábitos, nem os da alma, nem os do corpo, são alterações. Entre os hábitos, existem virtudes e vícios; mas, nem as virtudes e nem os vícios são alterações: a virtude é um certo acabamento (...), o vício é a destruição e o desarranjo daquela elevação interior (ekstásis)" (ARISTÓTELES. Física. VII, 3, 246 a 10-13). 
virtude <aretàs légomen>", porque ela exprime uma "héxis (hábito ou disposição) que merece louvor" (Ética a Nicômaco. I, 13, 1103a 5-10; cf. Aristóteles, 1985). Independentemente, pois, de ser consuetudinária ou racionalmente concebida, a héxis congrega duas instâncias: uma, no sentido de um hábito da alma, pelo qual Aristóteles define a héxis como uma disposição de estar bem ou mal disposto perante alguma coisa, seja diante de si mesmo ou perante um outro, ${ }^{65}$ outra, no sentido de uma conveniência, expressão de um procedimento estratégico, sobre o qual se assenta o dever ser e a obrigação cívica, a título, digamos, de obrigação ética ou moral.

Claro que, no que diz respeito à héxis enquanto virtude, mais exatamente à (dita por Aristóteles) aretê héxis proairetikê, à "inclinação do arbítrio em vista da excelência", ela não comporta, ao menos no que concerne à proairésis (à eleição ou decisão em favor de), e a título de petição de princípio, o "mal dispor-se perante alguma coisa", porquanto isso inevitavelmente possa ocorrer. É recorrente, todos sabemos, aliás, inevitável, o conflito ou descompasso costumeiro entre intenções e ações, ou entre propósitos e realizações. O que, todavia, aqui está em questão, na medida em que se pensa a aretê héxis (a "inclinação virtuosa"), é o arranjar-se em vista do melhor. Entretanto, por melhor é forçoso entender uma táxis (um arranjo) noético; porém, um arranjo (ordenamento) derivado, concomitante, do exercício do viver e do pensar, do agir e da disposição da consciência em vista da ação. ${ }^{66}$ Restrita ao pensar (ao ajuizamento racional mediante enunciados), a experiência (a fim de ser instrutiva) é o que se antecipa como fazer bem feito, como aretê ou comportamento de excelência: aquele pelo qual os cidadãos (balizados por conceitos de o melhor possível, de o mais justo, de o mais adequado, etc.) são levados a qualificar a si mesmos e a edificar a Pólis.

De um modo geral, Aristóteles concebeu a héxis sob dois amplos sentidos: um, passivo, como um estado ou modo adquirido de ser e de proceder em decorrência do meio (da vivência orientada pelos usos e costumes); outro, ativo, movido por uma disposição (no sentido de um arranjo, na forma de educação ou de instrução) do caráter ${ }^{67}$ - sentido em decorrência do qual a héxis expressa uma qualidade forjada, "imposta" à alma (mas sempre um modo de ser que se realiza e que se renova no decurso do tempo). Nos dois sentidos, tanto no ativo (no dispor-se do ânimo a fazer o que é devido ${ }^{68}$ ), quanto no passivo (no adquirir bons costumes pela convivência), Aristóte-

65 ARISTÓTELES. Metafísica. V, 20, 1022 b 10; cf. tb Categorias. 8, 8 b 26 - J. L. Ackill, Oxford: Clarendon Press, 1963.

66 ARISTÓTELES. Metafísica.V, 19, 1022b 1-3.

67 ARISTÓTELES. Ética a Nicômaco. III, 5, 1114b 10.

68 Na Ética a Nicômaco, Aristóteles faz a seguinte vinculação: héxis kaì poîêsis, ou seja, une a disposição ao fazer (ARISTÓTELES. Ética a Nicômaco. II, 6, 1106a 10-15). 
les deu à héxis o nome de virtude. No que concerne, todavia, a ese "impor" algo à alma, isso não significa subvertê-la, mas, sim, fundar (dis)posições balizadas no melhor e em vista do suposto como devido: seja a partir do consuetudinário, seja derivado do ajuizamento racional (do pensar filosófico). "Impor", ademais, também não significa subverter a alma humana em sua própria natureza, ao contrário, acompanhá-la. Ocorre que (sempre do ponto de vista de Aristóteles) nem a virtude e nem o vício alteram a natureza da alma, apenas, no caso da virtude, a eleva; e, do vício, promove desarranjos. "Elevar", no entanto, significa seguir o ritmo, acompanhar a natureza da alma, sem deprimi-la ou subjuagá-la. Daí, pois, porque a mesótês, o meio-termo (a moderação, como propuzeram grande parte dos filósofos) veio a ser por Aristóteles concebida como a medida justa, ${ }^{69}$ como o modo adequado de ser "que nos convém".

A héxis, enfim, como a supôs Aristóteles, expressa, sob todos os aspectos, um estado de alma (uma psychê héxis) forjado pelo querer, enquanto tal condizente com a natureza da própria alma, cujo querer lhe nasce de dentro, não se impõe ou vem de fora. ${ }^{70}$ A esse respeito, Aristóteles disse o seguinte de modo bem claro: "nenhuma virtude é gerada em nós por natureza" (Ética a Nicômaco. II, 1, $1103 a 19$ e 1103b 2; cf. Aristóteles, 1985); ${ }^{71}$ tampouco o vício. Quer dizer: a nossa natureza não nos dota, espontaneamente, nem de vícios e nem de virtudes, apenas facilita e consente. "Uma disposição se define mediante atividades" - disse ele ainda (idem, IV, 1122b 1-2; ibidem, 1985); ${ }^{72}$ e noutro lugar: cada um de nós "é como que o causador de suas próprias disposições" (idem, III, 5, 1114b 1-2; ib., 1985). ${ }^{73}$ Temos em nós, pois, por natureza, a faculdade, mas não nos tornamos bons ou maus sem exercício ou sem disposição deliberada. ${ }^{74}$ A natureza da alma, ou melhor, a nossa natureza humana forçosamente nos empurra na busca do melhor (mesmo que, por vezes, seja o pior), mas não nos mostra e tampouco nos dota espontânea e concretamente do bem e do mal.

Enfim, que a virtude careça de procura, de um dispor-se em vista do melhor, isso é fato. E, sendo assim, ou seja, não sendo o agir de excelência um modo humano natural de ser (algo, aliás, que coube a Sócrates ensinar no Mênon), teria então de carecer de arbítrio: seja derivado por vontade deliberada de um sujeito particular (integrado numa comunidade), seja por

69 Trata-se de um conceito pitagórico

70 ARISTÓTELES. Ética a Nicômaco. II, 3, 1104b 15.

71 ... tôn êthikôn phýsei hêmîn egginetai... Proposição com a qual Aristóteles retoma a tese, defendida por Sócrates no Mênon de Platão, segundo a qual não há mestre para a virtude.

72 hê héxis taîs energeíais horízetai.

73 ... tês héxeôs estí pôs aítios.

74 ARISTÓTELES. Ética a Nicômaco. II, 5, 1106a 5. 
uma coletividade de indivíduos que se unem em vista das concordâncias entre si. Quer dizer: o agir virtuoso (pensamos aqui no seu enunciado, enquanto indicação do que é suposto como devido) deve surtir de alguma fonte: ou dos usos e costumes (do consuetudinário), ou do ofício (noético) de filosofar, que, na perspectiva de Aristóteles, não dispensa, contudo, a experiência vivida (aquela consolidada pelos hábitos ou pelos usos e costumes). Mas não podemos mesmo assim esquecer que Aristóteles foi o discípulo predileto de Platão, que, por sua vez, o foi de Sócrates, e, este, de Arquelao, ${ }^{75}$ que fora discípulo e sucessor de Anaxágoras, tido como o primeiro a fundar, em Atenas, uma Escola Filosófica. ${ }^{76}$ Daí a necessidade, ainda que de modo breve, de dar uma mirada, sob esse aspecto, na relação de Aristóteles com os seus mestres de Atenas.

Pertence a Arquelao o principal postulado que deu sentido e orientou, em Atenas, a reflexão ética a partir de Sócrates. Arquelao supôs, como tese, que "o justo e o vício não nos são dados por natureza, mas impostos por leis". ${ }^{77}$ Com isso ele quis dizer que, tanto o suposto como virtuoso e o dado como vício, são concebidos por convenção, mais precisamente, são como tal reconhecidos a partir dos ditames da lei, e não por espontaneidade de nossa natureza. É, com efeito, por força da razão que nos impomos limites, do mesmo modo como é mediante empenho reflexivo que atribuímos ao bem e ao mal significados em dependência dos quais conferimos às ações humanas uma certa qualidade, que, enfim, por ela damos ao agir conotação moral (como sendo virtuoso ou vicioso). O certo é que, todos sabemos, em tal qualidade se infiltram inevitavelmente atitudes e valores subjetivos, e, sendo assim, só o que é consagrado pela tradição mereceria então ser considerado; mas tem ainda um problema: ocorre que o convencionado como bom ou mal não se manifesta diretamente na ação, inclusive, um pode se

75 "Arquelao (...) foiu aluno de Anaxágoras e mestre de Sócrates" (Diógenes Laércio. Vidas e doutrinas dos filósofos ilustres. II, 16 - DK 60 A 1). "Arquelao (...) discipulo de Anaxágoras de Clazomena e mestre de Sócrates..." (Suidas. Léxico Archélaos; DK 60 A 2). "Para Arquelao de Atenas (esse testemunho é de Sexto Empírico), mestre de Sócrates", "a Filosofia se restringia ao estudo da física e da ética <tò physikòn kaì êthikón>" (Sexto Empírico. Contra os Matemáticos, IX, 360 e VII, 14; DK 60 A 7 e A 6). Mestre foi traduzido de kathegêtês, que tem o sentido de "aquele que indicou o caminho ou que serviu de guia".

76 Anaxágoras "teve por sucessor Arquelao, do qual Sócrates foi discípulo" (Clemente de Alexandria. Misclelâneas <Strômateîs>, I, 63 - DK 59 A 7). "A Anaxágoras, sucederá seu discípulo Arquelao..." (Santo Agostinho. Cidade de Deus, VIII, 2 - DK 60 A 10).

77 "... tò dikaion kaì aischròn ou phýsei eínai, allà nómôi" (Suda. Léxico "Arquelao" - DK 60 A 2). Na tradução de Jean-Paul Dumont: "que le juste et le mal n'existent pas par nature, mais sont définis par la convention" (Dumont, 1988). 
passar pelo outro aos olhos do observador, algo que efetivamente não ocorre enquanto atributo da consciência racional ou aos olhos do sujeito (racional) agente, e, sendo assim, então só a razão humana é capaz de prover e de explicar os fundamentos sobre os quais se apoia o caráter moral da ação virtuosa (do agente racional).

O Mênon de Platão, diálogo em que Sócrates põe em questão a virtude, parte justamente desta pergunta: a ação virtuosa é algo que se aprende ou que se ensina; que se adquire pelo exercício ou que apenas "advém aos homens por natureza ou por alguma outra fonte?" (Mênon, 70a; cf. Platão, 2001). Na busca por uma resposta a essa questão, Sócrates, de saída, opta por perguntar pelo o que é a virtude? Ele se pergunta, primeiro, se somos capazes de saber racionalmente o que é a virtude, a fim de, posteriormente, questionar o que é ser virtuoso. Esta é a questão: se, de antemão, não soubermos o que é ser virtuoso, não estamos em condições de qualificar a nossa ação como sendo virtuosa. Sócrates supôs, em definitivo, como Platão, relativo à vida ética, uma anterioridade do ser em vista do agir: ele priorizou a definição (do que é ser virtuoso) antes do comportamento (da ação ou do agir virtuoso).

A partir de Sócrates e de Platão, o que veio a ser denominado de vida ética passou a ser considerado bem mais que um mero exercício de cidadania, que apenas arte da boa convivência no interior da Pólis. Através deles foi posto em questão justamente a virtus, a aretê (uma vitalidade, qualidade ou valor) inerente ao querer em dependência do qual o sujeito agente se dispõe a agir e obter como resultado uma ação virtuosa. ${ }^{78}$ Não se trata, com efeito, de algo que se deixa diretamente observar na ação, mas, sim, primeiro, na definição, naquilo que Platão, no Mênon, denominou de eîdos (da virtude), ou seja, um modo de ser específico (índole ou caráter), dentre os vários modos, graças ao qual o que é tido como virtuoso possa ser compreendido mediante uma definição única (um que é universal aplicável a todas as ações que denominamos de virtuosas). ${ }^{79}$ Daí que, tanto Sócrates quanto Platão, no que diz respeito à vida ética, punham sobretudo em questão a eîdos do comportamento, e, não a rigor, a ideia de um governo assentado exclusivamente na lei.

Claro que ambos reconheciam a importância da lei como instância reguladora do Estado e da vida dos indivíduos. Sobre esse aspecto, Platão dizia, inclusive, que a natureza humana requer a lei, que "privados da vigilância divina", tendo que gerir e ordenar a própria vida, caberia aos homens

78 PLATÃO. Mênon, 78b em diante.

79 PLATÃO. Mênon, 72c; em 75a: “... procuro <aquilo que é> o mesmo em todas as coisas" (na tradução de Maura Iglésias); a partir de 79c retoma a mesma questão. 
"conduzir e zelar por si mesmos", tal como o Universo "cuida de si" (O Político, 274 d; cf. Platão, 1997). A lei seria, pois, a expressão desse zelo, por ele denominado de "cuidado geral". O que, efetivamente, quer Sócrates, quer Platão colocaram em questão não foi o domínio da lei na vida da pólis, mas sim o elevado valor que os atenienses atribuíam à lei como se ela fosse o pressuposto e a garantia do bem-estar (da eudaimonía) da vida cívica.

A grande questão, enfim, que a partir deles se impôs foi a seguinte: a lei é, sim, um valor político a ser considerado, no entanto, a vida política do cidadão e a dos governantes não podem, em nome dela, se desassociar da vida ética, ou seja, de um comportamento fundado a partir das ideias do bem e do justo. Com efeito, mesmo que o bom e o justo resultem por fim indefiníveis enquanto conceitos (isso por força da absoluta unidade de compreensão a que estão constrangidos), eles, entretanto, se constituem em móveis (do ponto de vista de uma fundamentação teórica do agir) orientadores não só do agir, como também da pensar. Dá-se que, quanto ao agir (isto no diz respeito à vida ética), ele forçosamente deve coincidir com a virtude; quanto ao pensar (isto no que concerne à ciência), ele deve coincidir com a verdade.

Buscamos, com efeito, a unidade, mas nos debatemos constantemente com a pluralidade; aspiramos por harmonia, mas (com disse Heráclito) o conflito é a regra. ${ }^{80}$ Sobre isso podemos dizer que, racionalmente, sempre buscamos um princípio de unidade, e o motivo é porque a razão humana se descontrola no caos, se desestabiliza em seus domínios, caso não esteja apaziguada dentro de uma certa ordem. Das coisas, isto é fato, expressamos em geral qualidades, e, das ações, níveis de referências: por exemplo, quando dizemos que Vladimir é um homem bom, e que Jorge, em relação a ele, é ainda melhor, expressamos níveis de bondade, porém, de modo impróprio, visto que o que é bom não pode contradizer o que é bom, e, entre ambos, bom e bom, não pode haver meio termo.

"Os homens são bons de um único modo (salientou Aristóteles), e, maus, de várias maneiras" (Ética a Nicômaco. II, 6, 1106b 35; cf. Aristóteles, 1984). ${ }^{81}$ O insólito, todavia, apesar das dificuldades, é do meio termo (da mesótês, conforme expressão do mesmo Aristóteles), e não da plenitude, que, em geral, mais facilmente temos acesso! Eis então a nossa grande dificuldade: não realizamos plenamente o bem na ação porque não sabemos exatamente o que é a bondade em si, e não sabemos porque não consegui-

80 "O conflito é o pai e o rei de todas as coisas..." (Hipólito. Refutação de Todas as Heresias, IX, 9; DK 22 B 53); "A harmonia nasce somente dos contrários, pois ela é a unidade do misturado e a concordância dos opostos" (Nicômaco de Gerase. Introdução à Aritmética, II, 19, ed. Hiller, 115, 2; DK 44 B 10).

81 Não palavras de Aristóteles, mas uma sitação dele de um anônimo grego. 
mos, em sua plenitude, experimentá-la (realizá-la). Daí porque a Filosofia, desde o início, buscou romper, por um lado, com o excesso de força das convicções positivas que dominavam as opiniões comuns (convicções em dependência das quais a grande maioria se vangloriava de saber com segurança o que é certo e o que é errado, o que é decente ou indecente, o que é feio ou bonito, sem meio termo); por outro, teve a necessidade de sair em busca de princípios racionais que fundamentassem o agir virtuoso.

Em conclusão: do ponto de vista do consuetudinário, o que de geração em geração ia sendo acolhido como bom, qualificado pelos usos e costumes, acabava se impondo como uma convição comum, dado como hábito recorrente, tradicional. No caso da consuetudo dos latinos (fonte do nosso consueto), foram sobretudo dois qualificativos que, em sentido próprio, a definiaram: um, ser um bom hábito, tão bom que dispensava qualquer juízo de valor, eximia o questionamento e recebia apenas a alegação de que os ancestrais faziam assim; outro, ser um hábito comum e recorrente, tão comum que prescindia qualquer norma escrita, porquanto se impusesse como uma regra tácita acolhida por todos, ou, ao menos, pela grande maioria. ${ }^{82}$

Ao traduzirem éthos por suetus e êthos por mores, os latinos efetivamente fizeram jus à mikròn parekklînon (à pequena variação) suposta por Aristóteles em relação aos termos. Mas, também entre eles os dois termos detiveram igualmente o significado de assento (no sentido de habitação, morada), com o que designavam um modo de ser (de habitar ou de estar domiciliado), em referência ao qual o indivíduo era identificado com o seu núcleo de referência. ${ }^{83} \mathrm{O}$ que os latinos traduziram por virtus (referido à aretê)

82 "No comum falar consuetudinário erramos, por exemplo, quando dizemos que alguém quer ou não quer alguma coisa sem causa: ao dizer sem causa estamos apenas querendo afirmar sem uma causa externa, antecedente, e não efetivamente sem causa; o mesmo quando dizemos que o vaso está vazio, em que não falamos a linguagem dos físicos, para os quais o vazio não existe, simplesmente entendemos que o vaso não contém água, ou vinho, ou óleo... O mesmo pode ainda ser dito do átomo, na medida em que se move no vazio em virtude da gravidade e do peso, que se move sem causa, porque não intervém, nenhuma causa externa - communi igitur consuetudine sermonis abutimur, cum ita dicimus, velle aliquid quempiam aut nolle sine causa; ita enim dicimus sine causa, ut dicamus: sine externa et antecedente causa, non sine aliqua; ut, cum vas inane dicimus, non ita loquimur, ut physici, quibus inane esse nihil placet, sed ita, ut verbi causa sine aqua, sine vino, sine oleo ... De ipsa atomo dici potest, cum per inane moveatur gravitate et pondere, sine causa moveri, quia nulla causa accedat extrinsecus" (CÍCERO. De fato. I, 24 - Traité du Destin. Text établi et traduit para A. Yon. Paris: Les Belles Lettres, 1950).

83 Vinha a ser como se o indivíduo vestisse uma roupagem, portasse um distintivo, a ponto de, por exemplo, ser reconhecido por sua origem: "esse é um latino", "esse é um grego", etc.. Ambos os termos faziam igualmente referência ao que chamamos de cultura, ou seja, quando se dizia "o êthos dos gregos" ou "o mores dos latinos" significava o mesmo que dizer "a cultura dos gregos" ou "a cultura dos latinos", etc. 
se impôs como expressão da essência (do caráter ou índole) própria do que Cícero denominou de moribus domesticis: do status quo que cabia ao indivíduo de uma certa ascendência preservar, e, sobretudo, prover o enlevo, a fim de não viciar e nem desqualificar a força que movia e sustentava a sua ancestralidade. Nem o suetus e nem o mores eram expressão do universal, mas do doméstico (destituído de qualquer sentido rude de domesticação), enquanto modo de ser e de se dispor na vivência, modo de se produzir e de expressar a si mesmo. Tratava-se, pois, de um domínio civilizador, reconhecido como uma pertença, feito uma disposição interior que animava o indivívuo a se manter dentro dos limites instituídos por seu grupo. Daí que suetus e mores, na medida em que retinham a virtus, detinham um vigor enunciativo de qualidades nobres e valiosas de uma ascendência particular, ${ }^{84}$ e, não, a rigor, do humano em geral. Por isso, em muitos casos, se impunha ao indivíduo mostrar bem mais os mores que a si mesmo, evidenciar mais as qualidades do consueto que as de si próprio: exibir o ancestral e esconder a si mesmo.

Suetus e mores, assim como éthos e êthos, comportavam duas características comuns e prevalentes: a) o ser expressão de algo (hábitos ou costumes) dado no tempo e transferido de geração para geração como um bem valioso; b) ser algo comunitário e humanamente compartilhado, quer como modos de ser e de agir, quer como modo de lidar e dar solução aos próprios problemas e necessidades. Juntos, os dois termos comportavam uns quantos significados: a) o de assento, no sentido de o lugar (nos termos de um território, de uma ordem e de um destino) onde se erige a morada do indivíduo com o seu grupo, com suas tradições, dotes culturais, crenças religiosas, etc. Foi nesse sentido que o êthos, no contexto da cultura grega, se associou à instituição da pólis e à promulgação da politéia, ou seja, da constituição de um governo regido pela lei, fundado na ideia da ancestralidade e do direito; b) como modo de habitar o lugar onde se vive (não propriamente a habitação, mas a vivência em si mesma), característica que levou muitas vezes o termo êthos a ser traduzido por cultura, em referência a um

84 Fonte, muitas vezes, de desavenças; ao que poderia convir o que expressou La Fontaine em sua fábula: "Toda espécie... toda a classe, qualquer profissão... de néscios e ineptos tacham sempre os que dela não são. (...) Pelo avesso - o amor-próprio vos leva a exaltar os de ofícios iguais; esse o meio seguro e mais fácil, com que a própria pessoa elevais" ("O leão, o macaco e os dois burros". Trad. de Barão de Paranapiacaba. In: Fábulas de La Fontaine. Trad. de Bocage, Filinto Elísio, et alii. Gravuras de J. I. Grandville. Apresentação e seleção de João Alves das Neves. São Paulo: Melhoramentos, 1970, p.318). Texto original: "Toute espèce dit le Docteur, (Et je commence par la nôtre)/Toute profession s'estime dans son cœur,/ Traite les autres d'ignorantes,/ Les qualifie impertinentes, / Et semblables discours qui ne nous coûtent rien./ L'amour-propre au rebours, fait qu'au degré suprême/ On porte ses pareils; car c'est un bon moyen/ De s'élever aussi soi-même" (Le lion, le singe e les deux ânes, vv. 24-30). 
conjunto de características humanas instituídas, preservadas e aprimoradas através da comunicação e cooperação de indivíduos de uma mesma comunidade ou grupo; c) o de índole ou caráter, no sentido de uma natureza pessoal ou de um modo subjetivo de ser (sendo um pouco por natureza, outro pouco cumulativo, em decorrência de opções, decisões, preferências, e, claro, de algum empenho racional, que, cumulativamente, acabaram talhando ou forjando um certo modo de ser, etc.); d) enfim, o de uso ou costume, referido a um comportamento (testado ou experimentado no decurso do tempo) consuetudinário, transmitido e recebido em herança, quer na forma de uma ação balizada de fazer, quer como um resultado bem feito, numa palavra, como uma virtude (sujeita, todavia, a um constante aprimoramento).

Daí que a grande diferença entre éthos e êthos, além de meramente etimológica, veio a ser também semântica (decorrente da aplicação e reformulação de juizos de valores), e existencial (fruto de uma mescla constante entre ser e agir, pelo que se impunha um ajuizamento transformador, senão derivado da crítica, ao menos da consciência: do querer fazer melhor hoje relativo ao que foi feito ontem). Na medida em que o dado como éthos (o suetu), ou como êthos (os mores), não comportava ajuizamentos de valor (se certo ou errado), que bastava a mera justificativa tautológica do faço assim porque é assim que se faz, o indivíduo não entrava em crise, e, se não entrava, não se abria para a possibilidade da mudança ou para alguma alteração significativa. Por suposto não "evoluia", permanecia fechado no ancestral, indisponibilizado para qualquer perspectiva de ser melhor; na maioria das vezes se retraía, em vista do temor, de, em algum momento, vir a ser pior. Isolado da "austeridade" do pensar crítico, o indivídio restava apenas sujeito à autoridade da obrigação inferida do hábito (dos usos e dos costumes) e da experiência consolidada. De um modo geral, a Filosofia, e, com ela, a tarefa crítica do pensar, turva a serenidade dos que vivem no estabelecido; a educação filosófica faz toda a diferença: agita os que estão insatisfeitos, e traz insatisfação para os que vivem conformados.

Mas, enfim, de uma questão conjunta apenas semântica, éthos e êthos passaram isoladamente a comportar um viés conceitual diferenciado, porém, convergentes: o éthos se restringiu à expressão do conuetudinário, e, o êthos, passou a designar um modo filosófico de pensar os usos e os costumes. Foi justo por esse ponto de vista que o êthos angariou para si a força do ajuizamento crítico, e que passou a qualificar, em referência aos conceitos de bem e de mal, de justo e injusto, de belo e feio, a conduta humana. $\mathrm{O}$ seu fracasso, todavia, já se mostrou bem cedo, no momento em que os gregos (dos quais, nesse caso, os acusadores de Sócrates vieram a ser os ícones) requisitaram da Filosofia austeridade educadora: que o filósofo prescrevesse, por seu ofício, o bem viver cívico, e que, em definitivo, desse a todos saber o que é certo e o que é errado. 
SPINELLI, Miguel. On the differences between Ethos with epsilon and Ethos with eta. Trans/Form/Ação, São Paulo, v.32(2), 2009, p.9-44.

- ABSTRACT: The objective of this article is to describe the terms éthos (writed with epsilon) and êthos (with eta), that are in the same time different and complementary. This two terms are closely associates to the concepts of phýsis (of nature) and moîra (of necessity or destination) and this study wants to show how this interrelation is done.

- KEYWORDS: éthos, êthos, phýsis, moîra.

\section{Referências bibliográficas}

ARISTÓTELES. Física, ed. Henri Carteron. Paris: Les Belles Lettres, 1952.

Metafísica. edição e trad. de Valentín García Yebra. Madrid: Gredos, 1982.

Ética a Nicômaco, The Complete Works of Aristotle. The Revised Oxford Translation. Edited by J. Barnes, Princepton, 1984.

Traité du Ciel (suivi du traité pseudo-aristotélicien Du Monde). Ed. J. Tricot. Paris: Vrin, 1986.

Parties des animaux, traduction de J.-M. Le Blond, Paris: Flammarion, 1995.

Política. Edição bilingue. Trad. de António C. Amaral e Carlos de Carvalho Gomes, Lisboa: Vega, 1998.

CÍCERO. De fato/Traité du Destin. Text établi et traduit para A. Yon. Paris: Les Belles Lettres, 1950.

De finibus bonorum et malorum. With an english translation by $\mathrm{H}$. Rackham. Cambridge: Harvard University Press, 1999.

De natura deorum. With an english translation by H. Rackham. (Loeb Classical Library). Cambridge: Harvard University Press, 2000.

DIELS, Herman \& KRANZ, Walther. Die Fragmente der Vorsokratiker. 18 a ed., <Unveränderter Nachdruck der 6. Auflage 1951>, Zürich-Hildesheim, Weidmann, 1989 ;

DUMONT, Jean-Paul, DELATTRE, Daniel \& POIRIER, Jean-Louis. Les Présocratiques, Quetigny-Dijon, Gallimard, 1988.

ÉSQUILO. Théatre. Traduction nouvelle avec texte intégral... par Émile Chambry. Paris: Garnier Frères, 1964.

ESSER, H. "Éthos". In: COENEN, L., BEYREUTHER, E., \& BIETENHARD, H. (Org.). Dizionario dei Concetti Biblici del Nuovo Testamento. Trad. de A. Dal Bianco, B. Liverani e G. Massi, Bologna: Dehoniano, 1976.

LUCRÉCIO. Da natureza. Tradução e notas de Agostinho da Silva. São Paulo: Abril Cultural, 1980. 
LUCRÉCIO. De rerum natura. Introducción, traducción y Notas de Eduard Valentí Fiol. Barcelona: Bosch, 1985.

PLATÃO. Politico. Testo grego a fronte, trad. di P. Accatino. Bari/Roma: Laterza, 1997.

. República. Trad. di Franco Sartori. Con testo a fronte. Bari: Laterza, 1997. Mênon. Tradução de Maura Iglésias. São Paulo: Loyola, 2001.

SEXTO EMPÍRICO. Adversus Mathematicos. vols. 2-4. Edited by R. G. Bury. Cambridge: MA/ London: Harvard University Press/ W. Heinemann Ltd. (The Loeb Classical Library), 1971.

SÓFOCLES. Théatre de Sophocle. T.I: Ajax, Antigone, Électra, Oedipe Roi. T.II: Les Trachiniennes, Philoctète, Oedipe a Colone, Les Limiers. Traduction nouvelle avec texte, introduction et notes para Robert Pignarre. Paris: Garnier, 1958.

ZELLER, E. \& MONDOLFO, R. La Filosofia dei Greci nel suo Sviluppo Storico. Firenze: La Nuova Italia, 1967. 